Article

\title{
Comparison of Different Solar-Assisted Air Conditioning Systems for Australian Office Buildings
}

\author{
Yunlong Ma ${ }^{1, *}$ (i) , Suvash C. Saha ${ }^{1, *}$, Wendy Miller ${ }^{1}$ (D) and Lisa Guan ${ }^{2}$ \\ 1 School of Chemistry, Physics, and Mechanical Engineering, Queensland University of Technology (QUT), \\ 2 George Street, GPO Box 2434, Brisbane, QLD 4001, Australia; w2.miller@qut.edu.au \\ 2 University of Technology Sydney, Faculty of Design Architecture and Building, Ultimo, NSW 2007, \\ Australia; lisa.guan@uts.edu.au \\ * Correspondence: yunlong.ma@connect.qut.edu.au (Y.M.); suvash.saha@uts.edu.au (S.C.S.); \\ Tel.: +61-7-3138-2178 (Y.M.); +61-7-3138-1413 (S.C.S.)
}

Academic Editor: Jinqing Peng

Received: 7 September 2017; Accepted: 18 September 2017; Published: 22 September 2017

\begin{abstract}
This study has investigated the feasibility of three different solar-assisted air conditioning systems for typical medium-sized office buildings in all eight Australian capital cities using the whole building energy simulation software EnergyPlus. The studied solar cooling systems include: solar desiccant-evaporative cooling (SDEC) system, hybrid solar desiccant-compression cooling (SDCC) system, and solar absorption cooling (SAC) system. A referenced conventional vapor compression variable-air-volume (VAV) system has also been investigated for comparison purpose. The technical, environmental, and economic performances of each solar cooling system have been evaluated in terms of solar fraction (SF), system coefficient of performance (COP), annual HVAC (heating, ventilation, and air conditioning) electricity consumption, annual $\mathrm{CO}_{2}$ emissions reduction, payback period $(P B P)$, and net present value $(N P V)$. The results demonstrate that the SDEC system consumes the least energy in Brisbane and Darwin, achieving $56.9 \%$ and $82.1 \%$ annual energy savings, respectively, compared to the conventional VAV system, while for the other six cities, the SAC system is the most energy efficient. However, from both energy and economic aspects, the SDEC system is more feasible in Adelaide, Brisbane, Darwin, Melbourne, Perth, and Sydney because of high annual $S F$ and $C O P$, low yearly energy consumption, short $P B P$ and positive $N P V$, while for Canberra and Hobart, although the SAC system achieves considerable energy savings, it is not economically beneficial due to high initial cost. Therefore, the SDEC system is the most economically beneficial for most of Australian cities, especially in hot and humid climates. The SAC system is also energy efficient, but is not as economic as the SDEC system. However, for Canberra and Hobart, reducing initial cost is the key point to achieve economic feasibility of solar cooling applications.
\end{abstract}

Keywords: solar energy; desiccant dehumidification; absorption cooling; building simulation; EnergyPlus; economic feasibility; heating, ventilation, and air conditioning

\section{Introduction}

The increasing amount of energy consumption by buildings has caused widespread global attention to the social, environmental, and economic implications associated with it. Research has shown that the building sector is responsible for $32 \%$ of the world's total primary energy consumption [1] and nearly $34 \%$ of direct greenhouse gas (GHG) emissions globally [2]. In Europe, 39\% of the total primary energy is consumed by buildings, among which $26 \%$ is for residential houses and $13 \%$ for commercial architectures [3]. In China, the building industry accounts for $25-30 \%$ of the total national primary energy [4], while in the USA buildings represent $40 \%$ of the total national energy consumption and $40 \%$ of $\mathrm{CO}_{2}$ emissions [5]. A similar situation happens in Australia, where the building industry consumes 
$40 \%$ of the national electric energy and contributes to $27 \%$ of the GHG emissions [6]. Commercial buildings in particular consume approximately $61 \%$ total building energy consumption and contribute one third of total building GHG emissions in Australia. Additionally, the heating, ventilation, and air conditioning (HVAC) system installed in buildings is the largest energy consumption contributor, accounting for $68 \%$, followed by $19 \%$ for lighting and $13 \%$ for others [6].

Australia has a variety of climatic zones and is currently facing the challenge of dramatic peak electricity demand due to the high penetration rate of residential and commercial HVAC systems. Therefore, developing innovative HVAC technology towards sustainability is vitally crucial for Australia to decrease the nation's electricity energy consumption and GHG emissions. Fortunately, the abundant solar energy resource in Australia makes solar cooling available [7]. Because peak electricity demand due to wide use of air conditioning matches peak solar irradiance, it is feasible to assume that solar air conditioning technology would be highly desirable in Australia as a means to reduce peak demand, energy consumption and GHG emissions. In addition, solar air conditioning has been widely believed as an appealing alternative for traditional HVAC systems in the world because of its energy efficient, inexhaustible, and eco-friendly features [8].

Therefore, this study aims at investigating the energy savings potential of different solar-assisted cooling systems for a typical office building in different Australian climates and assessing their economic feasibility. Specifically, this paper will compare the performance of solar desiccant-evaporative cooling (SDEC), combined solar desiccant-compression cooling (SDCC), and solar absorption cooling (SAC), with a referenced conventional vapor compression variable-air-volume (VAV) system, in terms of the technical, environmental, and economic aspects. This study will cover all Australian capital cities, including Adelaide, Brisbane, Canberra, Darwin, Hobart, Melbourne, Perth, and Sydney. The purpose of this investigation is to identify whether solar-assisted air conditioning systems are technically, environmentally and economically feasible for Australian commercial buildings.

\subsection{Solar Energy in Australia}

The solar energy resource in Australia is abundant. It is reported that the average solar radiation collected in Australia is about 58 million petajoules (PJ) per year, which is almost ten thousand times the nation's annual energy consumption [9]. Figure 1 shows the annual mean daily solar irradiation in Australia [7]. It demonstrates that Western Australia, Northern Territory, and northern Queensland areas have excellent solar energy resources, with more than $22 \mathrm{MJ} / \mathrm{m}^{2}$ per day. South Australia, southeast Queensland, and New South Wales have good solar energy potentials with about $19 \mathrm{MJ} / \mathrm{m}^{2}$ per day, while Victoria, the Australian Capital Territory, and Tasmania have comparatively lower solar energy resources, with just below $16 \mathrm{MJ} / \mathrm{m}^{2}$ per day.

There are three main methods to harness solar energy: active solar applications, passive solar strategies, and electricity generation through solar engines [9]. Active solar technology uses solar collectors to convert sunlight into useful thermal heat actively [10], which is normally used for domestic water heating, space heating and cooling. This technology is quite prevalent across Australia due to the merits of low running cost and government subsidies [9]. Passive solar technology is more about improving the passive efficiency of buildings, such as optimizing the building design in terms of building envelope, building systems and building orientation [10] in order to control the impact of solar radiation on the internal temperature of the building. In relation to electricity generation, solar thermal and solar photovoltaics (PV) are the technologies generally used for electricity production [9].

Although Australia has rich available solar energy resources, the solar energy utilisation in Australia is still on a small scale. It was estimated that solar energy only accounted for $0.1 \%$ of Australia's total primary energy depletion during 2007-2008 [7] and 2.4\% of all renewable energy use [9]. However, solar energy has become increasingly popular in Australia recently for both electricity production and direct-use applications. According to [6], there were 704,459 solar hot water systems installed around Australia in 2011, as well as many other low-temperature solar thermal applications such as solar ponds, solar air heating and solar air conditioning. The Australian PV Institute reported 
that since 2011, the solar PV installations in Australia have increased dramatically, reaching 1.7 million PV installations with a combined capacity of 6.2 gigawatts in 2017 [11]. In addition, the Australian Energy Statistics 2016 reported that for 2014-2015, solar PV accounted for 21.5 PJ energy consumption compared with solar hot water of $14.8 \mathrm{PJ}$ [12]. It is believed that with the development of solar panels and thermal storage technologies, as well as government financial support, the cost of solar technology will reduce significantly and thus, solar energy utilisation in Australia will become more advantageous in the future.

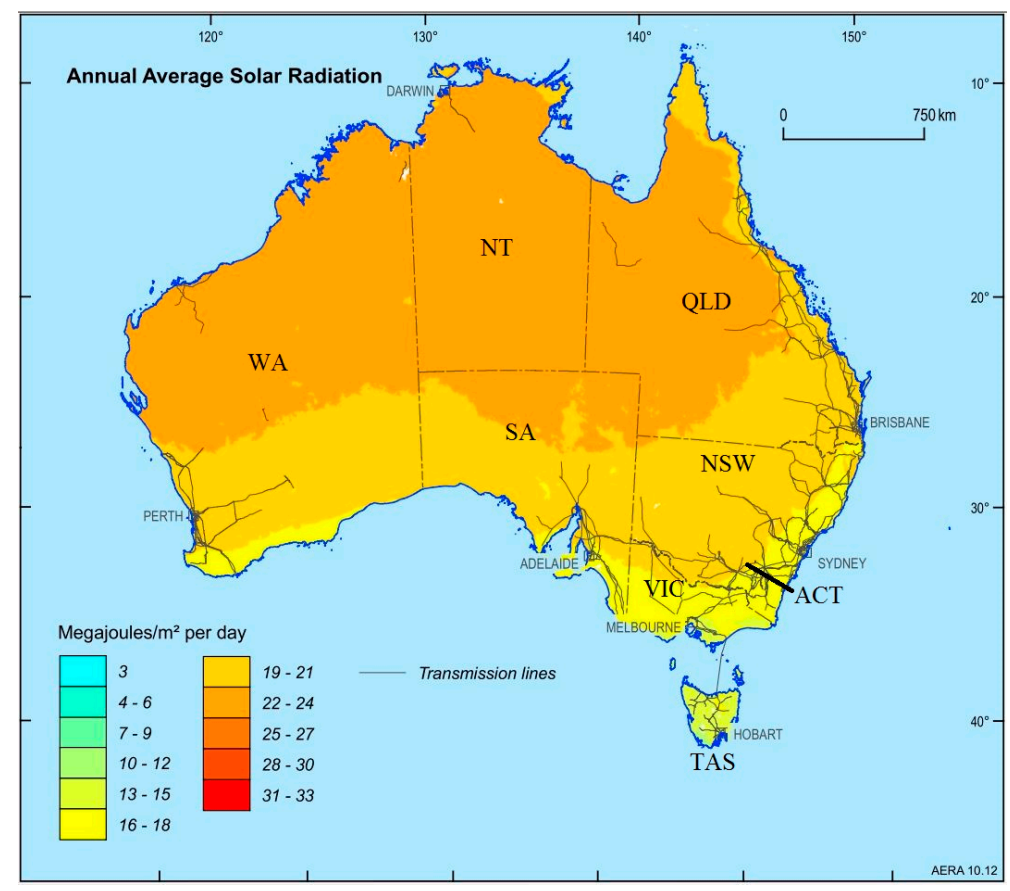

Figure 1. Annual average solar radiation in Australia [7].

\subsection{Solar Air Conditioning Technology Review}

Due to its environmentally friendly and energy efficient benefits, solar cooling has been widely recognised as a promising substitution for traditional air conditioning [8]. Solar air conditioning is a technology which converts solar energy into useful cooling or air conditioning for buildings. According to [13], solar cooling is divided into two broad groups: solar thermal cooling and solar electric cooling. Solar thermal cooling uses solar collectors to provide heat to drive a cooling process, which usually combines with thermally driven absorption or adsorption chillers. Solar electric cooling uses photovoltaics to generate electricity to drive classical motor driven vapour compression chillers. Nowadays, solar cooling applications have globally penetrated the world market in the USA, Europe, Japan, and China, with approximately 1000 solar cooling system installations [14]. Baniyounes et al. [6] indicates that solar absorption cooling systems are the most adopted solar thermal cooling technology in the global market, accounting for $70 \%$ of total installed solar thermal cooling systems. This is followed by solid solar desiccant cooling systems at $14 \%$, solar adsorption cooling systems at $13 \%$, liquid solar desiccant cooling systems at $2 \%$, and others at $1 \%$, which makes up the total market share percentage as is shown in Figure 2 below.

In the last several decades, solar-assisted cooling technology has widely been evaluated worldwide, including solar electric cooling powered by PV [15-17], solar absorption cooling [18-23], solar adsorption cooling [24,25], and solar desiccant cooling [26-35]. A theoretical modelling with experimental validation studied by Nie et al. [36] demonstrated that the solid desiccant cooling assisted by heat pump was more efficient than the conventional cooling system due to high efficient dehumidification capacity. These research results have also indicated that based on 
different solar cooling technologies and different climates, the energy savings could be $25 \%$ to $90 \%$ compared with the traditional HVAC system. In addition, there are also a number of comparative studies on the performances within various solar cooling systems, which include the comparison of solar absorption cooling with solar electric cooling [37-40], solar desiccant cooling with solar absorption cooling [41], and hybrid solar desiccant cooling with other solar cooling systems [42-45]. Gagliano et al. [46] reported that the hybrid solar desiccant integrated vapour compression cooling system could achieve $40 \%$ primary energy savings compared to the solar absorption cooling, and $150 \%$ savings respect to the conventional vapour compression cooling system. Khan et al. [47] found out that based on various collector areas, for Chennai city, the solar desiccant-assisted Dedicated Outdoor Air System (DOAS) integrated radiant cooling system could achieve $7.4 \%$ to $28.6 \%$ energy savings in comparison with the cooling coil-assisted DOAS radiant cooling system.

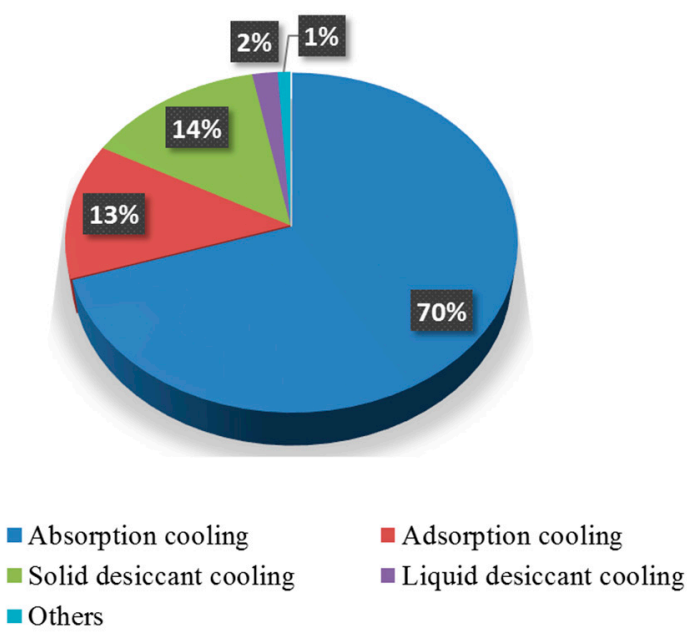

Figure 2. Solar cooling technology by categories.

The comparison results between different solar cooling systems have shown that overall the PV-integrated solar cooling system has higher solar fraction and lower primary energy consumption than the solar thermal absorption cooling system. If considering the excess electricity generation by PV, the grid-connected solar PV cooling system outperforms the solar thermal absorption cooling system from both energy and economic respects.

In Australia, the solar air conditioning technology research and development is still in the early stage. Baniyounes et al. [48] used the TRNSYS software to study the potential of solar absorption cooling for an office building under three subtropical climates in Australia. They indicated that by implementing $50 \mathrm{~m}^{2}$ solar collectors and $1.8 \mathrm{~m}^{3}$ hot water storage tank, the energy consumption of the solar absorption cooling system was only $20 \%$ of the conventional HVAC system. Alizadeh [49] conducted a feasibility study of a solar liquid desiccant air-conditioner (LDAC) for a commercial building in Queensland, Australia. The author found that by using LDAC, the operating costs could be decreased significantly in comparison with the equivalent gas-fired conventional cooling system, and the payback period was only five years. Goldsworthy and White [50] optimized a solar desiccant cooling system in Newcastle, Australia. They found that the system electric coefficient of performance (COP) could be above 20 if the desiccant wheel regeneration temperature was $70{ }^{\circ} \mathrm{C}$ with the 0.67 process-to-regeneration air flow ratio and 0.3 indirect evaporative cooler secondary-to-primary air flow ratio. In their another study [51], they found out that the frequency of high indoor temperature hours in Melbourne and Sydney could be reduced by improving the effectiveness of the indirect evaporative cooler, decreasing the regeneration temperature of the desiccant wheel, and increasing the solar collector areas. However, because of the high temperature and humidity ratio of the outdoor air, this effect was not dramatic in Darwin. Baniyounes et al. [41] compared the performance of solar desiccant evaporative cooling with solar absorption cooling for a school 
building in Gladstone and Rockhampton based on a TRNSYS simulation. They indicated that increasing solar collector areas would result in improved system COP and reduced energy consumption for both solar cooling systems. In addition, the solar desiccant evaporative cooling system had higher $C O P$ and solar fraction (SF) than the solar absorption cooling system. Kohlenbach and Dennis [52] conducted a comparative study between a solar PV air conditioning system and a solar thermal absorption cooling system with a referenced conventional vapor compression cooling system from both economic and environmental aspects for a commercial building in Brisbane and Sydney. The financial parameters were assumed as $2.5 \%$ inflation rate, $8 \%$ discount rate, 20 years system lifetime, and $0.17 \$ / \mathrm{kWh}$ electricity cost. They concluded that the solar absorption cooling system had a lower lifetime cost than the solar PV cooling system though they were both higher than the conventional cooling system. In addition, the solar thermal absorption cooling system was more economic until the electricity price exceeded $0.50 \$ / \mathrm{kWh}$, while the PV-based cooling system was more economic when the electricity price exceeded $0.55 \$ / \mathrm{kWh}$. In addition, the PV-based system resulted in the lowest GHG emissions due to the excess power generation over the lifetime.

From the above survey, it can be seen that the solar desiccant cooling technology is an appealing alternative to the conventional cooling system for the merits of low driving temperature, high COP and relatively short payback period characteristics. Solar absorption cooling is another popular alternative, with a relatively low driving temperature and the potential for large energy conservation. However, the life cycle cost of the solar absorption cooling system is relatively high. In addition, the solar electric cooling technology has the largest energy savings potential but at the same time has high life cycle cost. Although there is some research about solar cooling in Australia, little studies have been evaluated on the comparison between different solar-assisted cooling systems under all Australian capital cities. Additionally, there is no comprehensive study on the feasibility of different solar-assisted cooling systems from the technical, environmental and economic aspects. Therefore, this paper will lead to the investigation and comparison of different solar-assisted cooling systems for all eight Australian capital cities. The results from this study are expected to contribute to the fulfilment of the Australian Government targets of $5 \%$ and $80 \% \mathrm{CO}_{2}$ emissions reduction on 2000 levels by 2020 and 2050 [53].

\section{Methodology}

\subsection{Weather Data}

A whole year $(8760 \mathrm{~h})$ transient modelling by EnergyPlus is conducted for each Australian capital city to investigate the performance of the proposed SDEC, SDCC, and SAC systems. Therefore, the Australian Representative Meteorological Year (RMY) weather data is selected for EnergyPlus simulation. The latest RMY data files (historical period from 1967-2012) can be downloaded from Climate.OneBuilding website (http:/ / climate.onebuilding.org/default.html), which were developed in 2012 for the Australian National House Energy Rating Scheme (NatHERS) by the Australian Federal Department of Industry. The available solar radiation for each city is illustrated in Figure 3, which is derived from the RMY weather data files. It reveals that Darwin has the highest annual total solar radiation due to its stable solar radiation during the year. The solar radiation in Darwin in summer is not as high as in other cities (due to the tropical wet season) but it is much higher than others from April to October (the tropical dry season). Perth has the second largest annual total solar radiation, followed by Brisbane, Adelaide, Sydney, Canberra, Melbourne and Hobart.

Table 1 summarizes the climate indicators for each Australian capital city, which is also derived from the RMY data files. The outdoor design conditions are based on design days developed using $99.6 \%$ heating design temperatures and $0.4 \%$ dry-bulb (DB) and $0.4 \%$ wet-bulb (WB) cooling design temperatures. 


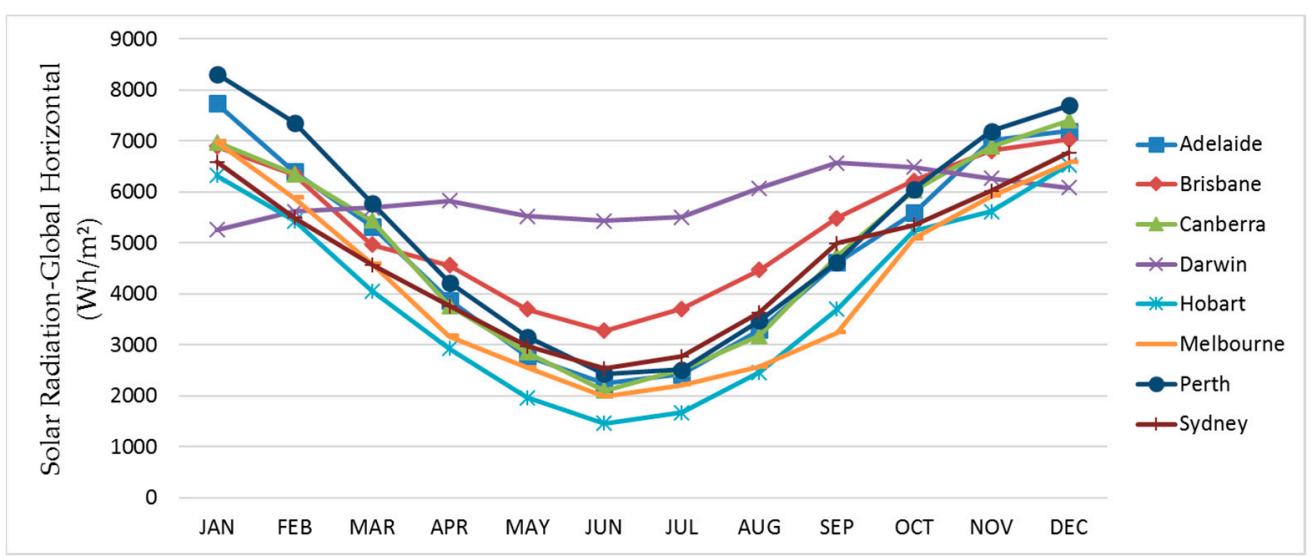

Figure 3. Solar irradiance for each capital city.

Table 1. Climatic indicators for Australian capital cities.

\begin{tabular}{cccccc}
\hline & & & \multicolumn{3}{c}{ Outdoor Design Conditions } \\
\cline { 4 - 6 } Location & CDD18 $^{\mathbf{1}}$ & HDD18 $^{\mathbf{2}}$ & \multicolumn{2}{c}{ Summer } & Winter \\
\cline { 4 - 6 } & & & DBT $\left({ }^{\circ} \mathbf{C}\right)$ & WBT $\left({ }^{\circ} \mathbf{C}\right)$ & DBT $\left({ }^{\circ} \mathbf{C}\right)$ \\
\hline Adelaide & 630 & 1024 & 37.5 & 19.1 & 4.7 \\
Brisbane & 1129 & 323 & 31.0 & 22.5 & 5.8 \\
Canberra & 225 & 2119 & 33.6 & 17.8 & -3.1 \\
Darwin & 3386 & 0 & 34.1 & 23.5 & 17.1 \\
Hobart & 61 & 2088 & 28.1 & 17.0 & 2.4 \\
Melbourne & 340 & 1288 & 34.8 & 18.8 & 4.7 \\
Perth & 764 & 782 & 37.2 & 19.2 & 4.0 \\
Sydney & 610 & 641 & 31.1 & 19.8 & 7.2 \\
\hline
\end{tabular}

${ }^{1}$ For any one day, when the mean temperature is more than $18{ }^{\circ} \mathrm{C}$, there are as many degree-days as degrees Celsius temperature difference between the mean temperature for the day and $18^{\circ} \mathrm{C}$. Annual cooling degree-days (CDDs) are the sum of the degree-days over a calendar year [54]; ${ }^{2}$ For any one day, when the mean temperature is less than $18{ }^{\circ} \mathrm{C}$, there are as many degree-days as degrees Celsius temperature difference between the mean temperature for the day and $18{ }^{\circ} \mathrm{C}$. Annual heating degree-days (HDDs) are the sum of the degree-days over a calendar year [54].

It indicates that Darwin has the highest CDD18, followed by Brisbane, Perth, Adelaide and Sydney respectively. Canberra has the highest HDD18, followed by Hobart and Melbourne. This indicates that Darwin and Brisbane are cooling dominated climates, while Canberra, Hobart and Melbourne are heating dominated climates. Other cities, however, are balanced or temperate climates. It is apparent that Darwin and Brisbane have the highest wet-bulb temperature in a summer design day, which indicates more humid climates and therefore more potential for desiccant cooling. However, Adelaide and Perth have the highest dry-bulb temperature but moderate wet-bulb temperature in a summer design day. This means that the dehumidifying potential in these two cities is not as dramatic as in Darwin and Brisbane.

\subsection{Building Model Description}

The studied building is Building Type B (long axis East-West), which is defined by Australian Building Codes Board (ABCB) to represent an archetypal medium office building in Australia. The building has three storeys with a carpark. Each floor has five conditioned zones, and each floor has one core zone and four perimeter zones with $3.6 \mathrm{~m}$ depth. The total conditioned area is $2003.85 \mathrm{~m}^{2}$ and conditioned window-to-wall ratio (WWR) is 0.4. The Building Type B geometry and the zone division are shown in Figure 4 below [55]. 

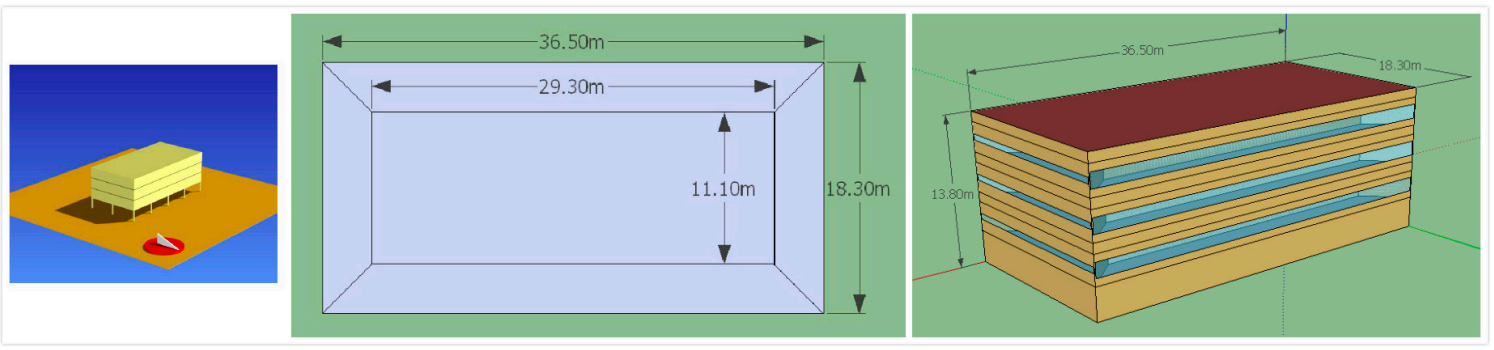

Figure 4. Building Type B model geometry and zone division [55].

The building physical properties and general modelling assumptions are listed in Table 2 [56].

Table 2. Building physical properties and general modelling assumptions [56].

\begin{tabular}{|c|c|}
\hline Building Features & Value \\
\hline Footprint dimensions & $36.5 \mathrm{~m} \times 18.3 \mathrm{~m}$ \\
\hline Gross conditioned floor area & $2003.85 \mathrm{~m}^{2}$ \\
\hline Aspect ratio & $2: 1$ \\
\hline Floor-to-ceiling height & $2.7 \mathrm{~m}$ \\
\hline Plenum wall height & $0.9 \mathrm{~m}$ \\
\hline Car park height & $3 \mathrm{~m}$ \\
\hline Roof & Metal deck, air gap, foil, roof space, $\mathrm{R} 2.0$ batts, $13 \mathrm{~mm}$ acoustic tiles $\left(\mathrm{U}=0.277 \mathrm{~W} /\left(\mathrm{m}^{2} \cdot \mathrm{K}\right)\right)$ \\
\hline Floor & $175 \mathrm{~mm}$ concrete slab with carpet $\left(\mathrm{U}=1.32 \mathrm{~W} /\left(\mathrm{m}^{2} \cdot \mathrm{K}\right)\right)$ \\
\hline Exterior wall & $200 \mathrm{~mm}$ heavy weight concrete, R1.5 batts, $10 \mathrm{~mm}$ plasterboard $\left(\mathrm{U}=0.554 \mathrm{~W} /\left(\mathrm{m}^{2} \cdot \mathrm{K}\right)\right)$ \\
\hline Window & Single $6 \mathrm{~mm}$ clear glass, conditioned WWR $=0.4\left(\mathrm{U}=5.89 \mathrm{~W} /\left(\mathrm{m}^{2} \cdot \mathrm{K}\right)\right)$ \\
\hline Lighting power density & $15 \mathrm{~W} / \mathrm{m}^{2}$ \\
\hline Equipment load density & $15 \mathrm{~W} / \mathrm{m}^{2}$ \\
\hline Occupant density & $10 \mathrm{~m}^{2} /$ person \\
\hline Lighting schedule & $91.5 \mathrm{~h} /$ week \\
\hline Equipment schedule & $97.45 \mathrm{~h} /$ week \\
\hline Occupancy schedule & $53.75 \mathrm{~h} /$ week \\
\hline HVAC operation schedule & $60 \mathrm{~h} /$ week, 06:00-18:00, Monday to Friday \\
\hline Infiltration rate & 1 air change per hour $(\mathrm{ACH})$, no infiltration during HVAC operation \\
\hline Outside air rate & $10 \mathrm{~L} / \mathrm{s}$ per person \\
\hline HVAC set-points & $\begin{array}{c}24 \pm 1{ }^{\circ} \mathrm{C}, 50 \% \text { relative humidity for cooling with setback temperature of } 38^{\circ} \mathrm{C} ; 20 \pm 1^{\circ} \mathrm{C} \\
\text { for heating with setback temperature of } 12^{\circ} \mathrm{C}\end{array}$ \\
\hline Referenced HVAC system & VAV with reheat, water-cooled chiller \\
\hline
\end{tabular}

\subsection{System Design and Configuration}

\subsubsection{The Referenced Conventional VAV System}

The conventional VAV system is constructed as a base case scenario for the building model validation and as the reference for comparison with the solar-assisted cooling systems. The system input parameters and system diagram are shown in Table 3 and Figure 5, respectively.

Table 3. Simulation input parameters of the referenced conventional VAV system [57].

\begin{tabular}{cccc}
\hline Parameters & Value & Parameters & Value \\
\hline Chiller & \multicolumn{3}{c}{ Boiler } \\
\hline Chiller type & Reciprocating & Boiler type & Hot water \\
Chiller COP & 3.5 & Fuel type & Electricity \\
Condenser type & Water cooled & Boiler efficiency & 0.8 \\
Chilled water design set-point & $7 / 13^{\circ} \mathrm{C}$ & Hot water design set-point & $82 / 71^{\circ} \mathrm{C}$ \\
Condenser water design set-point & $29.4 / 35^{\circ} \mathrm{C}$ & Hot water pump head & $179,325 \mathrm{~Pa}$ \\
\hline Supply \& Return Air Fan & \multicolumn{4}{c}{ Design Supply Air } \\
\hline Fan total efficiency & 0.7 & Design set-point temperature \\
Fan delta pressure & $500 \mathrm{~Pa}$ & Design set-point humidity ratio & $0.008 \mathrm{~kg} / \mathrm{kg}$ \\
\hline
\end{tabular}




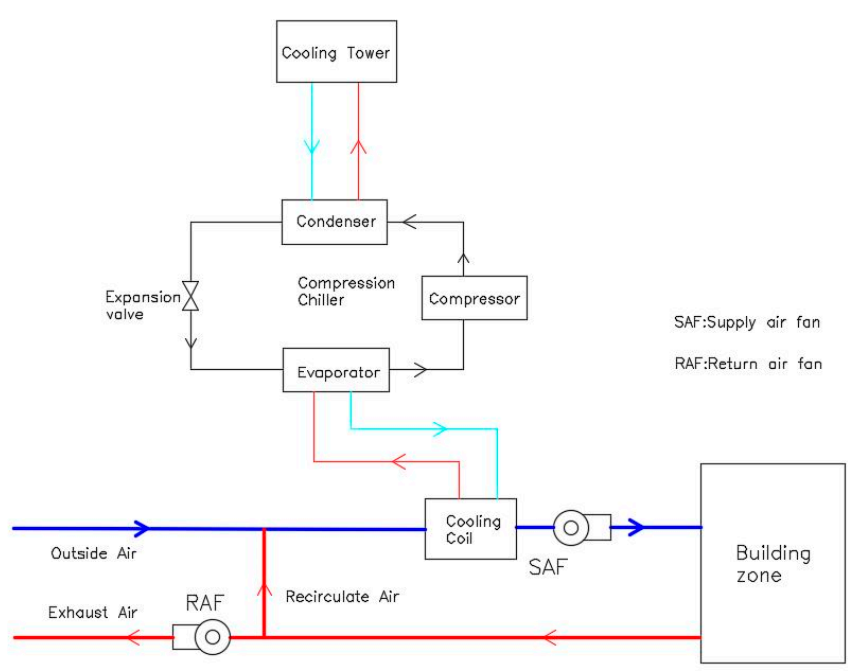

Figure 5. Schematic diagram of the conventional vapor compression cooling system.

\subsubsection{SDEC System}

A typical SDEC system usually consists of three parts: (1) solar thermal collectors, a hot water storage tank, and a backup heater, which are collectively comprised of the solar subsystem; (2) a desiccant wheel (DW), a sensible air-to-air heat exchanger (HX), and a regeneration air heater, which together consist of the desiccant subsystem; and (3) evaporative coolers (EC). The SDEC system schematic diagram is demonstrated in Figure 6 below [55].

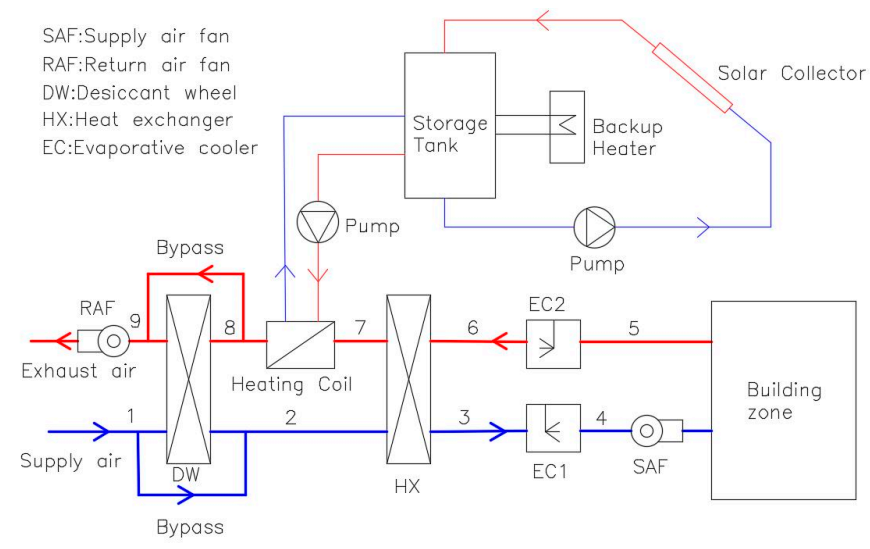

Figure 6. Schematic diagram of the SDEC system [55].

To reduce regeneration energy consumption, energy management control strategies have been applied to the system so that the desiccant subsystem is operating only when the outdoor air humidity ratio is greater than $0.008 \mathrm{~kg} / \mathrm{kg}$. The control strategies are accomplished through a sensor that provides an on/off signal to solar subsystem water pumps. When the outside air humidity ratio is under the control actuator set-point, the solar regenerative hot water pump will be off to disable the solar hot water loop so that the desiccant wheel and regeneration air heater are not in operation. This would significantly avoid unnecessary backup heater energy consumption while at the same time achieve low unmet hours during occupied cooling [55].

\subsubsection{SDCC System}

In the SDCC system, the EC 1 in Figure 6 is replaced by a cooling coil connected with a conventional vapor compression chiller, which is shown in Figure 7 below. This scenario is assumed 
to use the same equipment for the solar subsystem and the desiccant subsystem adopted in the SDEC system. The outside air is firstly dehumidified by the desiccant wheel to deal with the latent load, and then mixed with the recirculate air. The mixed supply air is then further cooled by the cooling coil. As only sensible load is handled in the cooling coil, the chiller capacity is significantly reduced compared to the referenced conventional VAV system. It assumes that the chiller COP, chilled water design set-point, and condenser water design set-point are the same with the referenced conventional VAV system. Thus, for the vapor compression chiller, fans and design supply air conditions, the simulation parameters can be referenced from Table 3 in Section 2.3.1. The same outdoor air humidity ratio control strategy with the SDEC system is applied to the SDCC system.

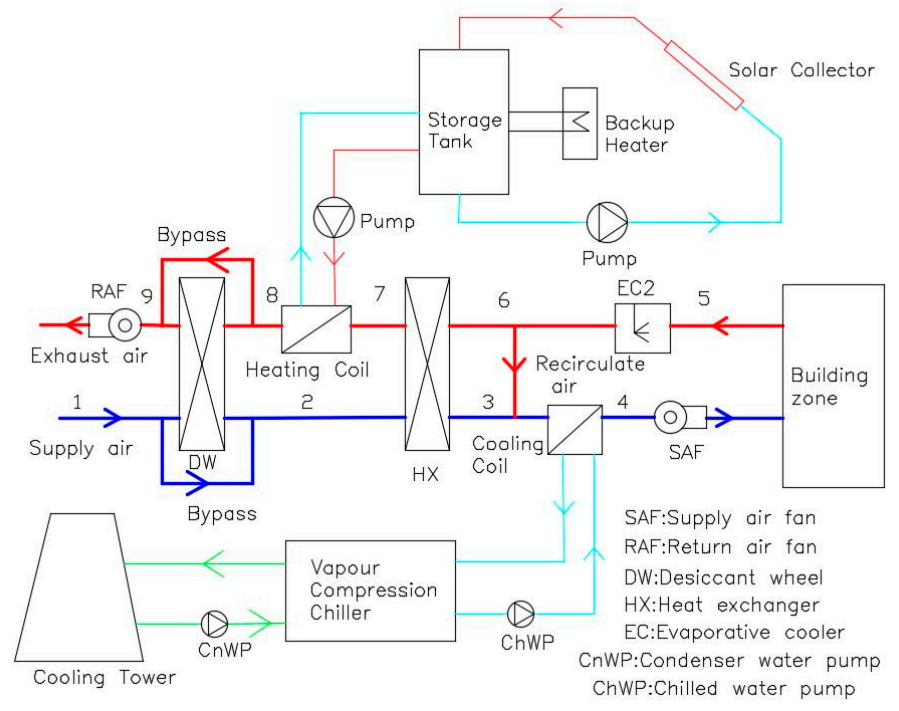

Figure 7. Schematic diagram of the SDCC system.

\subsubsection{SAC System}

The SAC system uses a thermally driven absorption chiller to provide the cooling effect. Cooling is achieved by an absorption cooling cycle. Solar thermal heat is supplied to the absorption chiller generator through a solar collector loop subsystem. The SAC system schematic diagram is illustrated in Figure 8. The input parameters for fans and design supply air conditions can also be referenced from Table 3 in Section 2.3.1. The modelling and input parameters for the absorption chiller will be discussed in Section 2.4.3.

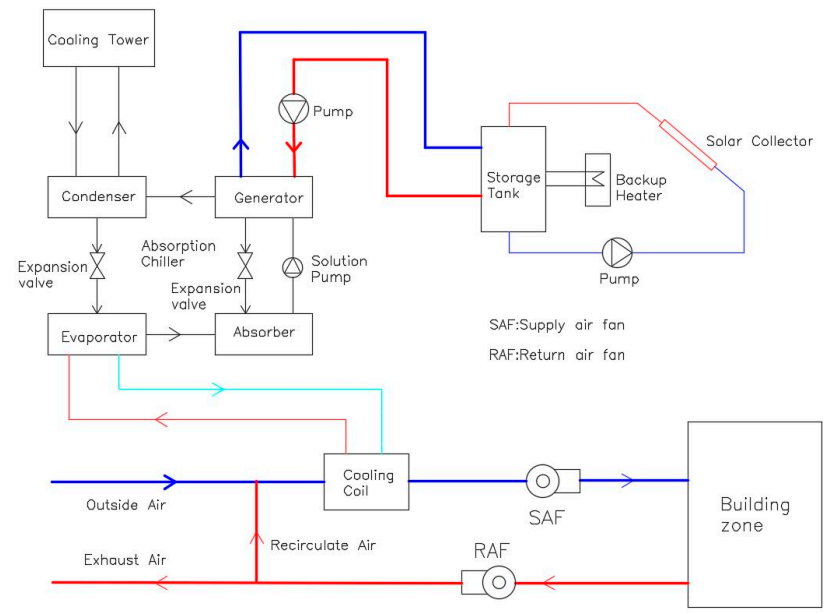

Figure 8. Schematic diagram of the SAC system. 


\subsection{Main System Components Modelling and Input Parameters}

\subsubsection{Solar Thermal Collectors}

Solar thermal collectors convert solar energy into usable thermal heat to drive thermally driven cooling process. In this study, the flat plate solar thermal collectors are selected because they are cost-effective for low temperature applications such solar heating and cooling [58]. In addition, the flat plate solar thermal collectors are able to provide $100{ }^{\circ} \mathrm{C}$ hot water, which is sufficient for solar desiccant cooling and single effect solar absorption cooling [59]. The governing equations for the modelling of the solar thermal collectors are expressed as [60]:

$$
\begin{gathered}
Q_{\text {Solar }}=\eta_{\text {Solar }} \times A_{c} \times I, \\
\eta_{\text {Solar }}=c_{0}+c_{1} \times \frac{T_{\text {in }}-T_{a}}{I}+c_{2} \times \frac{\left(T_{i n}-T_{a}\right)^{2}}{I},
\end{gathered}
$$

where $\eta_{\text {Solar }}$ is the solar thermal collector overall efficiency; $A_{c}$ is the gross area of the solar thermal collector in $\mathrm{m}^{2} ; I$ is the total incident solar radiation in $\mathrm{W} / \mathrm{m}^{2} ; T_{i n}$ is the collector inlet temperature of the working fluid in ${ }^{\circ} \mathrm{C} ; T_{a}$ is the ambient air temperature in ${ }^{\circ} \mathrm{C} ; c_{0}$ is the collector optical efficiency; $c_{1}$ and $c_{2}$ are the collector heat loss coefficients. The simulation input parameters for the solar collector loop components are listed in Table 4.

\begin{tabular}{|c|c|c|c|}
\hline Parameters & Value & Parameters & Value \\
\hline Solar Thermal Collector & & Backup Heater & \\
\hline Collector type & Flat plate & Backup heater fuel type & Electricity \\
\hline Collector tilt & $25^{\circ}$ & Backup heater efficiency & 1 \\
\hline Collector loop water flow rate & $0.019 \mathrm{~kg} /\left(\mathrm{s} \cdot \mathrm{m}^{2}\right)$ & Backup heater capacity & $100 \mathrm{~kW}$ \\
\hline Collector area & $576 \mathrm{~m}^{2}$ & Regenerative hot water loop & \\
\hline Collector optical efficiency $c_{0}$ & 0.753 & Storage tank volume & $30 \mathrm{~m}^{3}$ \\
\hline Collector heat loss coefficient $c_{1}$ & $-5.2917 \mathrm{~W} /\left(\mathrm{m}^{2} \cdot \mathrm{K}\right)$ & Hot water design set-point & $75^{\circ} \mathrm{C}$ \\
\hline Collector heat loss coefficient $c_{2}$ & $0.00638 \mathrm{~W} /\left(\mathrm{m}^{2} \cdot \mathrm{K}^{2}\right)$ & Hot water loop flow rate & $2.4 \mathrm{~kg} / \mathrm{s}$ \\
\hline Collector outlet water temperature & $90^{\circ} \mathrm{C}$ & Regeneration air heater capacity & 300 kW \\
\hline
\end{tabular}

Table 4. Input parameters for the solar collector loop components simulation [55].

According to the authors' previous study [55], a storage capacity of $30 \mathrm{~m}^{3} / 576 \mathrm{~m}^{2}$ with $100 \mathrm{~kW}$ backup heater capacity gives the lowest system life cycle cost. The regenerative hot water loop water flow rate is set to $2.4 \mathrm{~kg} / \mathrm{s}$ because it assumes $30^{\circ} \mathrm{C}$ temperature difference between the regeneration air heater water inlet and outlet. Other input parameters are also referenced from [55].

\subsubsection{Desiccant Cooling Subsystem}

The desiccant cooling subsystem includes a rotary desiccant wheel, a sensible air-to-air heat exchanger, and the evaporative coolers. The desiccant wheel is the key component in the desiccant cooling subsystem which deals with both sensible and latent heat transfer between the process and regeneration air streams. In EnergyPlus this model is a balanced flow desiccant heat exchanger which assumes the same air volume flow rate and face velocity through the regeneration and process air stream sides. Its performance is specified through the performance data that predicts the outlet temperature and humidity ratio of the regeneration air stream based on the entering regeneration and process air stream conditions and face velocity. The governing equations for the modelling of the desiccant wheel are [60]:

$$
\begin{aligned}
& R T O=B_{1}+B_{2} \times R W I+B_{3} \times R T I+B_{4} \times\left(\frac{R W I}{R T I}\right)+B_{5} \times P W I+B_{6} \times P T I+B_{7} \times\left(\frac{P W I}{P T I}\right)+B_{8} \times R F V, \\
& R W O=C_{1}+C_{2} \times R W I+C_{3} \times R T I+C_{4} \times\left(\frac{R W I}{R T I}\right)+C_{5} \times P W I+C_{6} \times P T I+C_{7} \times\left(\frac{P W I}{P T I}\right)+C_{8} \times R F V,
\end{aligned}
$$


where $R T O$ is regeneration outlet air dry-bulb temperature in ${ }^{\circ} \mathrm{C} ; R W I$ is regeneration inlet air humidity ratio in $\mathrm{kg} / \mathrm{kg}$; RTI is regeneration inlet air dry-bulb temperature in ${ }^{\circ} \mathrm{C} ; P W I$ is process inlet air humidity ratio in $\mathrm{kg} / \mathrm{kg} ; P T I$ is process inlet air dry-bulb temperature in ${ }^{\circ} \mathrm{C} ; R F V$ is regeneration (and process) air face velocity in $\mathrm{m} / \mathrm{s} ; B_{n}$ is temperature equation coefficient; $R W O$ is regeneration outlet air humidity ratio in $\mathrm{kg} / \mathrm{kg}$; and $C_{n}$ is humidity ratio equation coefficient.

The coefficients of $B_{n}$ and $C_{n}$ are referenced from the manufacturer's data (EDC-3550-200) [61], which are shown in Table 5 . It has good dehumidification ability that could dehumidify the outdoor air humidity ratio below $0.005 \mathrm{~kg} / \mathrm{kg}$, and it is able to deal with $69,753 \mathrm{~m}^{3} / \mathrm{h}$ nominal process air volume. A humidity ratio control set-point of $0.005 \mathrm{~kg} / \mathrm{kg}$ is applied on the desiccant wheel process air outlet node for dehumidifying control purposes.

Table 5. Coefficients for desiccant wheel temperature and humidity ratio equations [61].

\begin{tabular}{llllllll}
\hline B1 & B2 & B3 & B4 & B5 & B6 & B7 & B8 \\
\hline-27.18302 & -184.97 & 1.00051 & 11603.3 & -50.755 & -0.0168467 & 58.2213 & 0.598863 \\
\hline C1 & C2 & C3 & C4 & C5 & C6 & C7 & C8 \\
\hline 0.01213878 & 1.09689 & -0.000026 & -6.3389 & 0.00938196 & 0.0000521186 & 0.0670354 & -0.0001608 \\
\hline
\end{tabular}

The sensible air-to-air heat exchanger is a flat plate heat exchanger that presents equal flow rate in the process and regeneration air streams. It assumes no heat losses to the ambient environment. It is modelled using the following equations [60]:

$$
\begin{gathered}
\varepsilon_{H X}=\frac{t_{2}-t_{3}}{t_{2}-t_{6}}, \\
t_{2}-t_{3}=t_{7}-t_{6},
\end{gathered}
$$

where $\varepsilon_{H X}$ is the heat exchanger effectiveness; $t_{2}$ and $t_{3}$ is heat exchanger process air inlet and outlet dry-bulb temperature in ${ }^{\circ} \mathrm{C}$; $t_{6}$ and $t_{7}$ is heat exchanger regeneration air inlet and outlet dry-bulb temperature in ${ }^{\circ} \mathrm{C}$.

For the evaporative coolers, they are modelled using Equation (7), which assumes a constant effectiveness model and the wet-bulb temperature remains constant between the inlet and outlet of the direct evaporative cooler [60].

$$
T_{d b, \text { out }}=T_{d b, \text { in }}-\varepsilon\left(T_{d b, \text { in }}-T_{w b, \text { in }}\right),
$$

where $T_{d b, o u t}$ is the dry-bulb temperature of the air leaving the cooler in ${ }^{\circ} \mathrm{C} ; T_{d b \text {,in }}$ is the dry-bulb temperature of the air entering the cooler in ${ }^{\circ} \mathrm{C} ; T_{w b, \text { in }}$ is the wet-bulb temperature of the air entering the cooler in ${ }^{\circ} \mathrm{C}$; and $\varepsilon$ is the evaporative cooler effectiveness.

The input parameters for the modelling of the desiccant wheel, heat exchanger and evaporative

\begin{tabular}{|c|c|c|c|}
\hline Parameters & Value & Parameters & Value \\
\hline Desiccant Wheel (DW) & & Heat Exchanger (HX) & \\
\hline DW nominal air flow rate & $19.4 \mathrm{~m}^{3} / \mathrm{s}$ & HX type & Flat Plate \\
\hline DW nominal electric power & $186 \mathrm{~W}$ & HX nominal air flow rate & $19.4 \mathrm{~m}^{3} / \mathrm{s}$ \\
\hline DW nominal air face velocity & $4 \mathrm{~m} / \mathrm{s}$ & Ratio of supply to secondary $h \cdot A$ value & 1 \\
\hline Minimum regeneration temperature & $50^{\circ} \mathrm{C}$ & Nominal electric power $(\mathrm{W})$ & 0 \\
\hline Direct evaporative cooler (EC) & & Nominal supply air inlet temperature & $54{ }^{\circ} \mathrm{C}$ \\
\hline Coil maximum efficiency & 0.9 & Nominal supply air outlet temperature & $32.4{ }^{\circ} \mathrm{C}$ \\
\hline Recirculating water pump power & $50 \mathrm{~W}$ & Nominal secondary air inlet temperature & $20{ }^{\circ} \mathrm{C}$ \\
\hline
\end{tabular}
coolers are listed in Table 6 [55], which are derived from the manufacturers' data [61,62].

Table 6. Simulation input parameters for the desiccant cooling subsystem components [55]. 


\subsubsection{Absorption Chiller}

In the SAC system, a single-effect absorption chiller is selected. This is because the single-effect absorption cooling cycle requires a relatively low temperature heat source of about $70{ }^{\circ} \mathrm{C}$ to $120^{\circ} \mathrm{C}$, which can be provided by the flat plate solar collectors [57]. In EnergyPlus, the modelling of the absorption chiller is based on performance curves: Generator Heat Input Part Load Ratio Curve and Pump Electric Use Part Load Ratio Curve [60]. The Generator Heat Input Part Load Ratio Curve determines the ratio of the generator thermal input $\left(Q_{G e n}\right)$ to the chiller evaporator cooling effect $\left(Q_{\text {evap }}\right)$, which is expressed by:

$$
\text { GeneratorHeatInputRatio }=\frac{C_{A}}{P L R}+C_{B}+C_{C} \times P L R .
$$

The Pump Electric Use Part Load Ratio Curve determines the ratio of the actual absorber pumping power to the nominal pumping power, which is given as:

$$
\text { PumpElectricInputRatio }=C_{A}+C_{B} \times P L R+C_{C} \times P L R^{2},
$$

where PLR is the absorption chiller part load ratio; and $C_{A, B, C}$ are the part load ratio curve coefficients for the chiller generator and solution pump.

Then, the water temperature leaving the evaporator of the absorption chiller can be calculated according to the chiller evaporator cooling effect and the evaporator entering water temperature.

$$
T_{\text {evap }, \text { out }}=T_{\text {evap,in }}+\frac{Q_{\text {evap }}}{C_{p, \text { evap }} \times m_{\text {evap }}}
$$

where $T_{\text {evap }, \text { out }}$ is the absorption chiller evaporator outlet water temperature in ${ }^{\circ} \mathrm{C} ; T_{\text {eavp, in }}$ is the chiller evaporator inlet water temperature in ${ }^{\circ} \mathrm{C} ; C_{p, \text { evap }}$ is the specific heat of chiller evaporator inlet water in $\mathrm{J} / \mathrm{kg} /{ }^{\circ} \mathrm{C}$; and $m_{\text {evap }}$ is the chiller evaporator water mass flow rate in $\mathrm{kg} / \mathrm{s}$.

The condenser heat transfer and condenser leaving water temperature are calculated using the following equations:

$$
\begin{gathered}
Q_{\text {cond }}=Q_{\text {evap }}+Q_{\text {Gen }}+Q_{\text {pump }}, \\
T_{\text {cond,out }}=T_{\text {cond,in }}+\frac{Q_{\text {cond }}}{C_{p, \text { cond }} \times m_{\text {cond }}},
\end{gathered}
$$

where $Q_{\text {cond }}$ is the absorption chiller condenser heat transfer rate in $\mathrm{kW} ; T_{\text {cond,out }}$ is the absorption chiller condenser outlet water temperature in ${ }^{\circ} \mathrm{C} ; T_{\text {cond,in }}$ is the chiller condenser inlet water temperature in ${ }^{\circ} \mathrm{C} ; C_{p, \text { cond }}$ is the specific heat of chiller condenser inlet water in $\mathrm{J} / \mathrm{kg} /{ }^{\circ} \mathrm{C} ; m_{\text {cond }}$ is the absorption chiller condenser water mass flow rate in $\mathrm{kg} / \mathrm{s} ; Q_{G e n}$ is the absorption chiller generator heat input in $\mathrm{kW}$; and $Q_{\text {pump }}$ is the absorption chiller solution pump power rate in $\mathrm{kW}$.

The input parameters for modelling the single-effect absorption chiller are summarised in Table 7 , which are referenced from EnergyPlus (U.S. Department of Energy, Washington DC, USA) dataset in the software.

Table 7. Simulation input parameters for the absorption chiller.

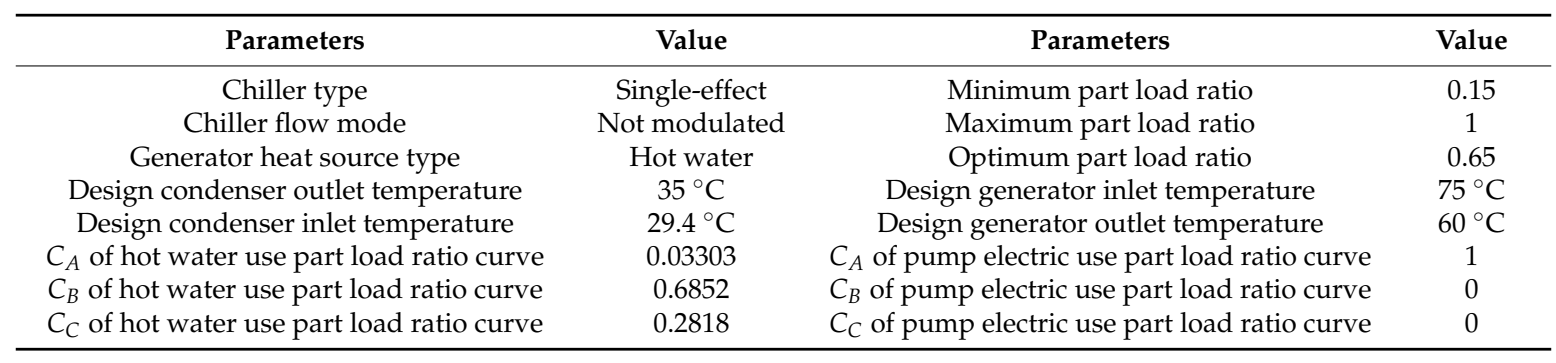




\subsection{Building Model Validation}

The building model is validated based on a self-validation in terms of the building loads, building energy consumption, and building indoor temperature using the referenced conventional VAV system.

Figure 9 demonstrates the annual building energy consumption of the referenced VAV system for each city. Figures 10 and 11 illustrate the monthly building cooling and heating load, respectively. From the figures it can be seen that comparing within all eight cities, the building cooling energy consumption strongly corresponds with the building cooling load profile and the building heating energy consumption strongly corresponds with the building heating load profile for each city. Darwin has the highest annual total building cooling load, followed by Brisbane, resulting in the most annual cooling energy consumption, followed by Brisbane, while Canberra has the largest building heating load, followed by Hobart and Melbourne, leading to the highest annual heating energy consumption, followed by Hobart and Melbourne as well. These results are also coincident with the climatic features in each city discussed in Section 2.1.

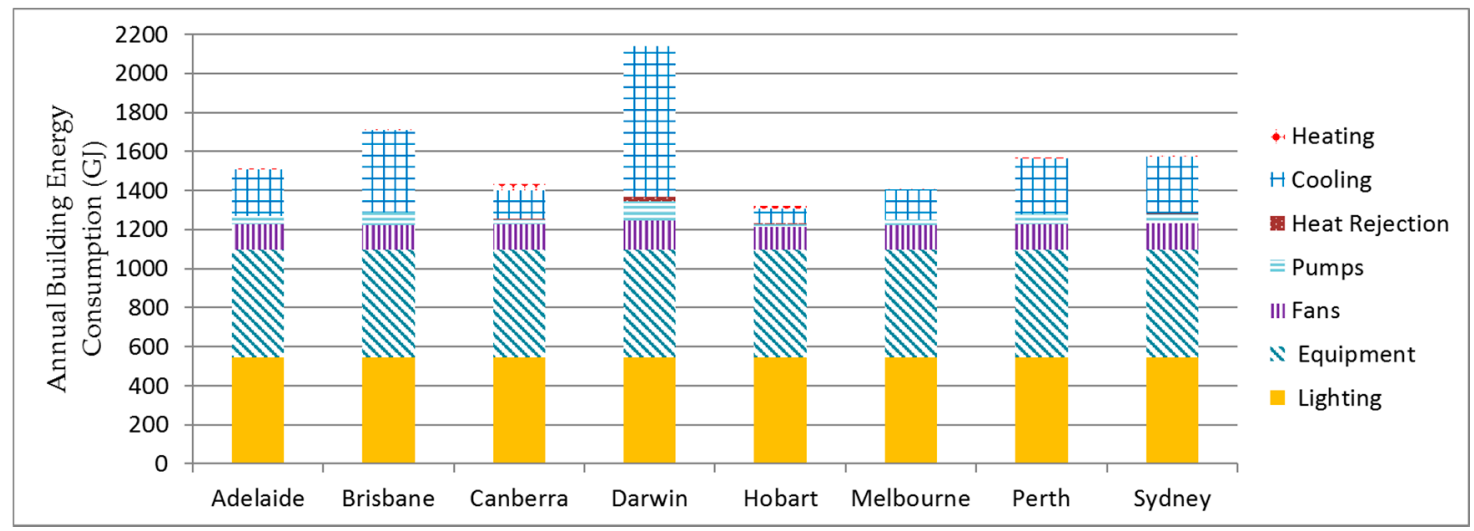

Figure 9. Annual building energy consumption of the conventional VAV system.

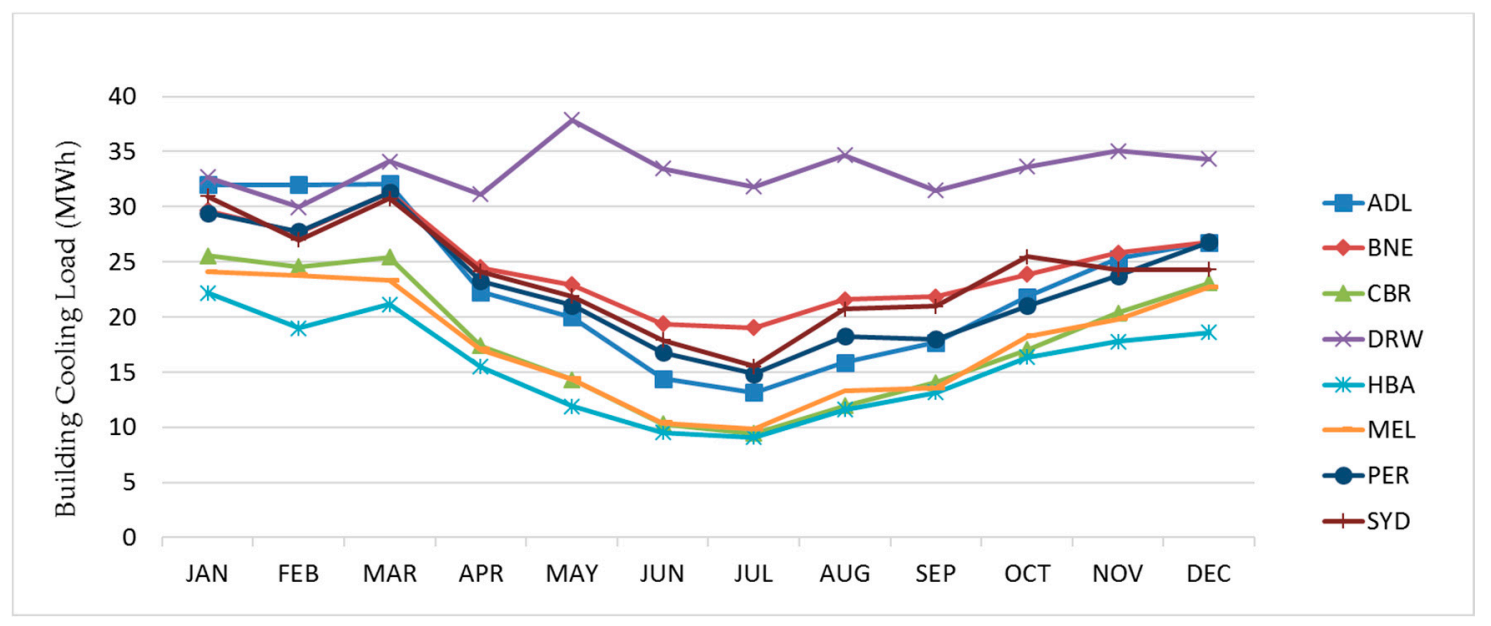

Figure 10. Monthly building cooling load.

In addition, comparing Figures 10 and 11, in winter seasons there are both cooling and heating requirements, but cooling is still dominant for this type of office building because of substantial heat gains from interior lighting and equipment. Therefore, the total cooling energy consumption is dramatically larger than the total heating energy consumption in each city as is shown in Figure 9. This also provides confidence for the building model calibration. 


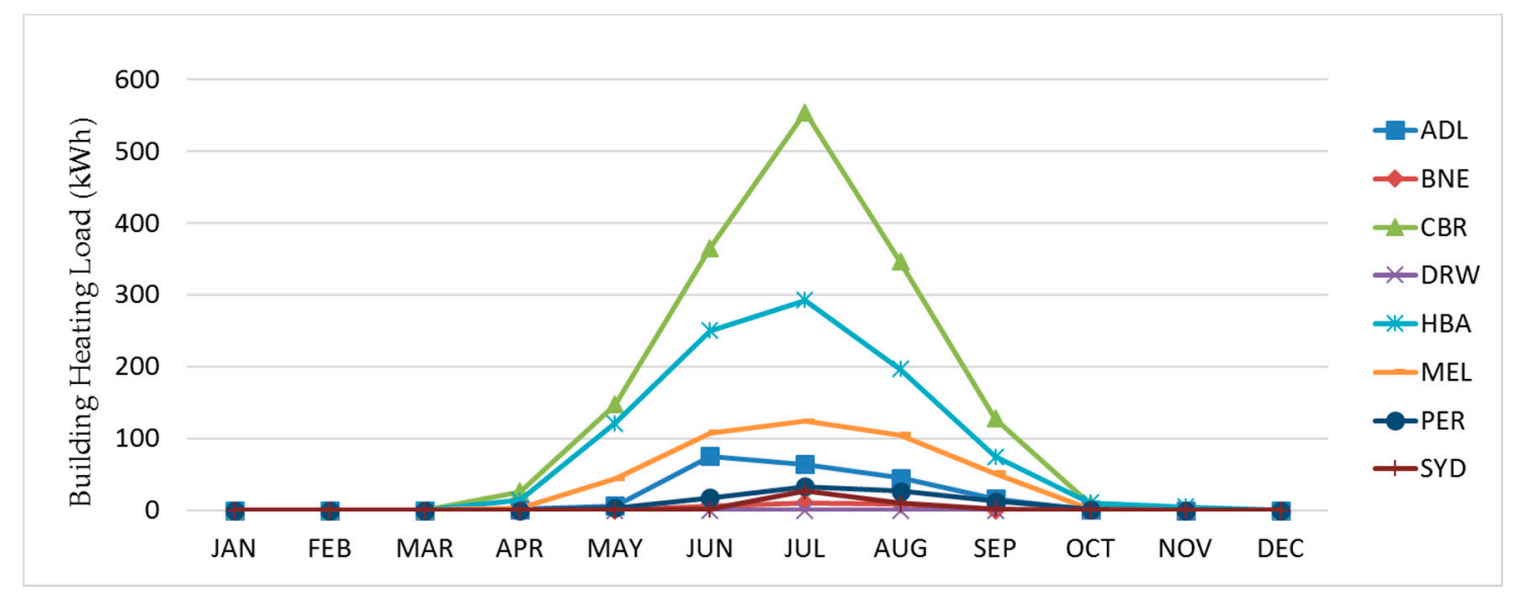

Figure 11. Monthly building heating load.

Figure 12 shows the monthly averaged building indoor temperature of the referenced VAV system for all cities. It is clear that the building indoor temperature can meet the cooling design set-point of $24 \pm 1{ }^{\circ} \mathrm{C}$ in summer for all cities. However, in winter months from May to August, the average building indoor temperature is around $22{ }^{\circ} \mathrm{C}$ for Canberra, Hobart, and Melbourne. This is because although heating is required in these months, cooling is still dominant, especially at times such as from 10 a.m. to 4 p.m. when the lighting and equipment utilization percentages reach the maximum fraction, leading to the mixed heating and cooling mode of the HVAC system operation. This could also be verified in the previous discussion.

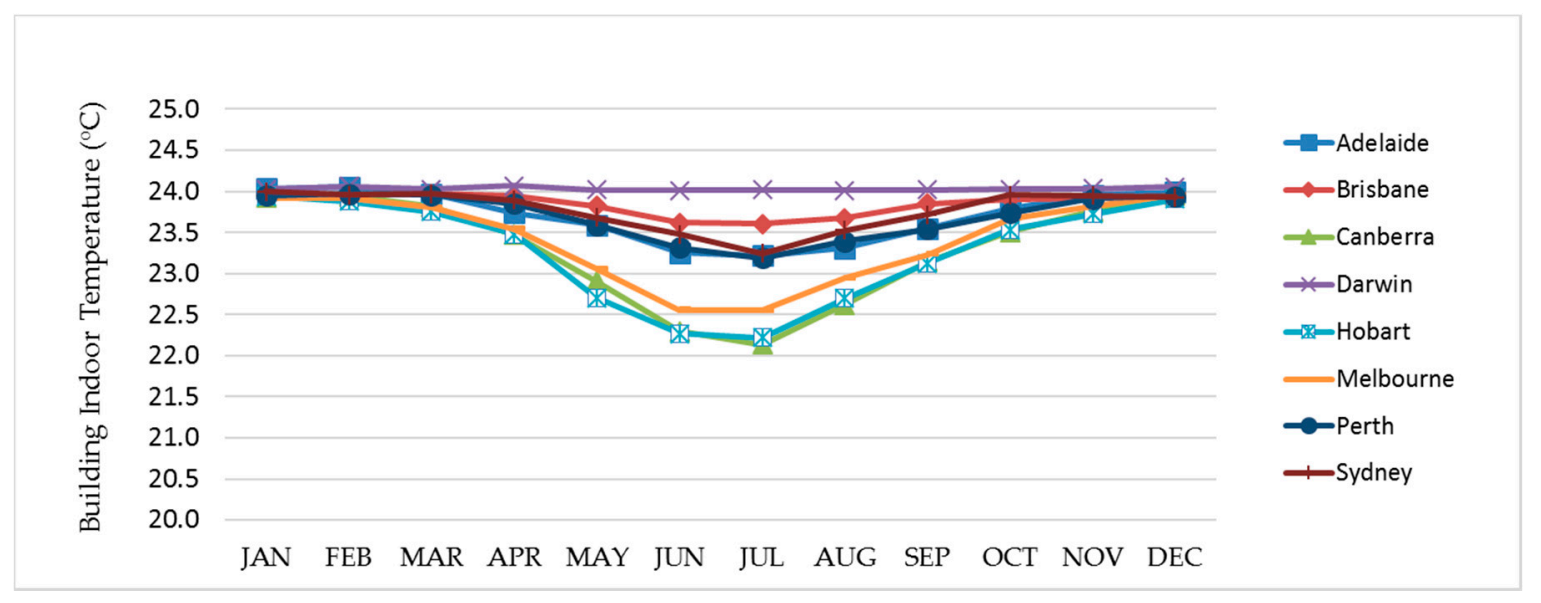

Figure 12. Monthly building indoor temperature of the conventional VAV system.

\section{Results and Discussion}

\subsection{Technical Performance Analysis}

\subsubsection{Solar Fraction}

Solar fraction refers to the solar energy contribution to the solar cooling system. It is defined as the percentage of usable solar contribution to the total solar cooling system energy input. Whenever the solar energy is inadequate to power the cooling system, a backup heater is generally in operation to provide supplementary heat. Therefore, the solar fraction can be defined in the following equation:

$$
S F=\frac{E_{\text {Solar }}}{E_{\text {in }}}=\frac{E_{\text {Solar }}}{E_{\text {HVAC }}+E_{\text {Solar }}},
$$


where $E_{\text {Solar }}$ is the available solar heat input in GJ (gigajoule); $E_{\text {in }}$ is the total system energy input in GJ; and $E_{H V A C}$ is the system electrical-related consumptions in GJ, including fans, pumps, electric chiller, cooling tower, backup heater, evaporative coolers, and desiccant wheel motor, et al.

As a pump controller is included to disable the solar subsystem pumps whenever the desiccant dehumidification is not needed for the SDEC and SDCC systems. The SF is only counted when the solar subsystem pumps are in operation. For comparison purpose, the annual $S F_{y}$ is used, which is expressed as:

$$
S F_{y}=\frac{\sum_{i=1}^{j} E_{\text {Solar }_{i}}}{\sum_{i=1}^{j} E_{i n_{i}}},
$$

where $j$ is the number of time steps in a year for the solar hot water pump in operation.

Figure 13 below shows the annual solar fraction results of different solar cooling systems for each city. It indicates that for all eight capital cities, the SDEC system has the highest annual SF. The SAC system has the second largest annual SF except Hobart, which the annual SF of the SAC system is the lowest among three solar cooling systems. Comparing the $S F$ results between all cities, for the SDEC system, Darwin has the highest annual SF of 0.82, followed by Brisbane of 0.78, Perth of 0.76, Sydney of 0.71, Adelaide of 0.67, Melbourne of 0.61, Canberra of 0.54, and Hobart of 0.49. For the SAC system, the largest annual SF happens in Brisbane with about 0.71, followed by Darwin of 0.69, Perth of 0.65, Adelaide of 0.60, Sydney of 0.59, Melbourne of 0.48, Canberra of 0.44, and Hobart of 0.33. While for the SDCC system, Brisbane has the largest annual SF of 0.63 , followed by Perth of 0.62 , Darwin of 0.61, Sydney of 0.55, Adelaide of 0.46, Melbourne of 0.42, Canberra of 0.41, and Hobart of 0.38. Overall, Darwin has the best annual SF performance, followed by Brisbane, Perth, Sydney, Adelaide, Melbourne, Canberra, and Hobart.

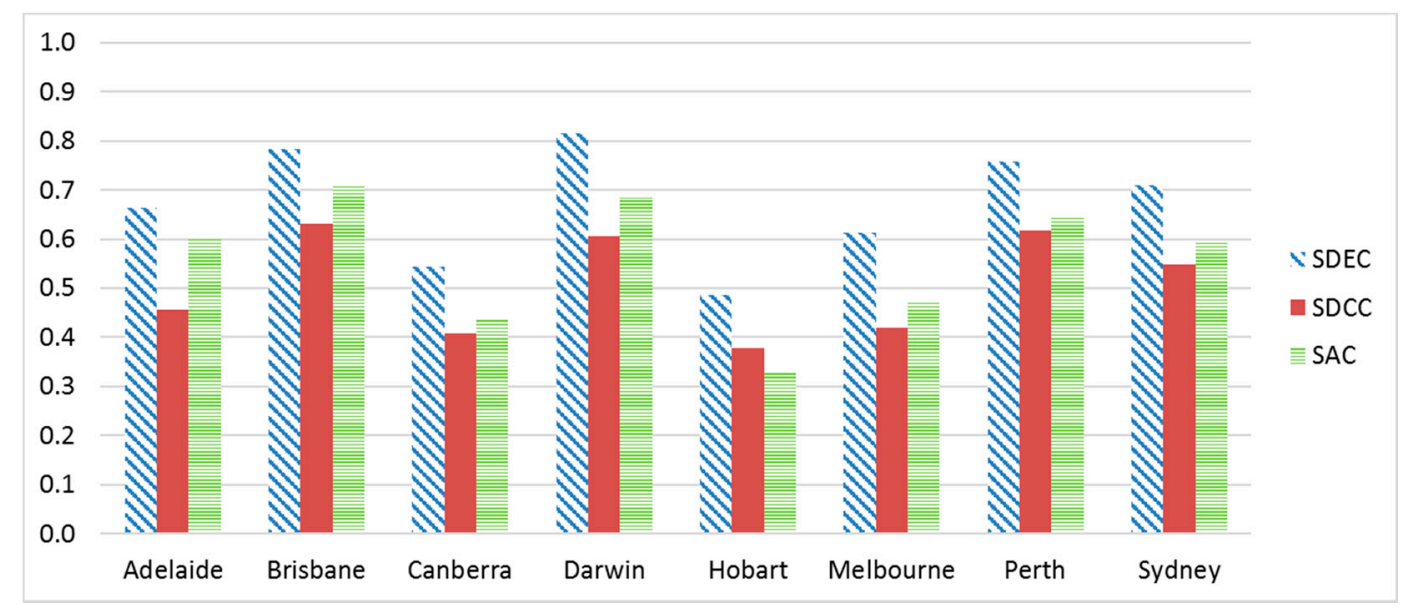

Figure 13. Annual solar fraction of different solar cooling systems.

In order to generalize the climatic conditions with the system solar fraction performance, a correlation between the annual average outdoor air humidity ratio and system annual $S F$ for different systems is demonstrated in Figure 14 below. It shows that the solar cooling system SF performance increases with the increase of the outdoor humidity ratio. The more humid of the climate, the higher the annual SF of the solar cooling systems. In addition, the SDEC system has the highest annual SF value, followed by the SAC system and SDCC system, which is consistent with the results discussed above. Based on the four-order polynomial correlation, the SDEC and SAC systems have a better polynomial fit than the SDCC system. 


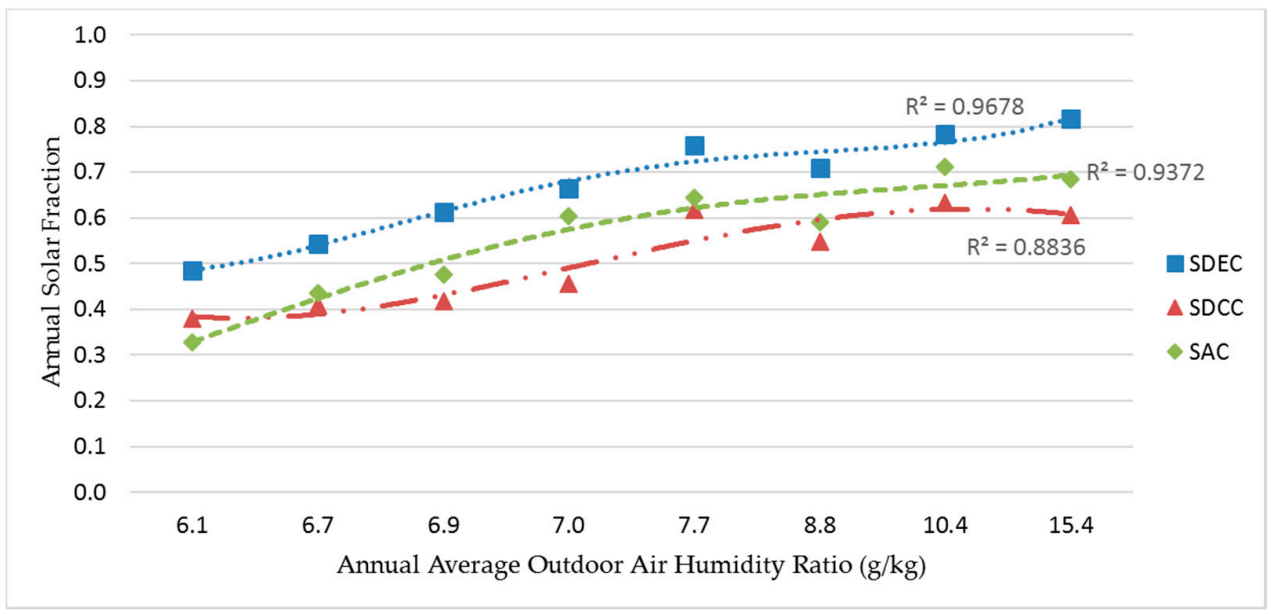

Figure 14. Correlation between outdoor air humidity ratio and annual SF.

\subsubsection{System Coefficient of Performance}

In this study, system electric COP is evaluated, which refers to the ratio of the system cooling demand to the total HVAC electricity consumption from the municipal electricity network. It can be expressed in Equation (15) below:

$$
C O P_{e l}=\frac{Q_{C}}{W_{H V A C}}
$$

where $Q_{C}$ is the system cooling effect in $\mathrm{kW}$; and $W_{H V A C}$ is the HVAC system electricity power consumption in $\mathrm{kW}$, including fans, pumps, chillers, backup heater, desiccant wheel motor, and cooling tower et al.

For the SDEC system using $100 \%$ outdoor air, the system COP is expressed as:

$$
C O P_{e l, S D E C}=\frac{Q_{C}}{W_{H V A C}}=\frac{m_{o} \times\left(h_{o}-h_{s}\right)}{W_{H V A C}} .
$$

For the SDCC system and SAC system using recirculation air mode, the system COP is expressed as Equations (17) and (18), respectively:

$$
\begin{gathered}
C O P_{e l, S D C C}=\frac{Q_{C}}{W_{H V A C}}=\frac{m_{o} \times\left(h_{o}-h_{p}\right)+Q_{\text {evap }, c h}}{W_{H V A C}}, \\
C O P_{e l, S A C}=\frac{Q_{C}}{W_{H V A C}}=\frac{Q_{\text {evap }, A b s}}{W_{H V A C}}
\end{gathered}
$$

where $m_{0}$ is the outdoor air mass flow rate in $\mathrm{kg} / \mathrm{s} ; h_{0}$ is the outside air enthalpy in $\mathrm{kJ} / \mathrm{kg}$; $h_{s}$ is the enthalpy of supply air after the evaporative cooler 1 (point 4 in Figure 6) in $\mathrm{kJ} / \mathrm{kg}$; $h_{p}$ is the enthalpy of process air after the air-to-air heat exchanger (point 3 in Figure 7) in $\mathrm{kJ} / \mathrm{kg}$; $Q_{\text {evap,ch }}$ is the SDCC system vapor compression chiller evaporator cooling rate in $\mathrm{kW}$; and $Q_{\text {evap, } A b s}$ is the SAC system absorption chiller evaporator cooling rate in $\mathrm{kW}$.

Also for comparison purposes, the system $C O P$ would be averaged on a yearly basis. The system $C O P$ is counted only when the key cooling components (desiccant wheel or chillers) are in operation for each time step and is expressed as:

$$
\operatorname{COP}_{e l, y}=\frac{\sum_{i=1}^{k} Q_{C_{i}}}{\sum_{i=1}^{k} W_{H V A C}}
$$

where $k$ is the number of time steps in a year for the desiccant wheel or chillers in operation. 
The annual system $C O P$ of different solar-assisted cooling systems are presented in Figure 15, where it is obvious that the SDEC system has a higher annual system electric COP than the other two solar cooling systems in all cities, while the SDCC system has the lowest annual system COP, except in Darwin and Hobart, where the lowest system electric COP is the SAC system. Due to high dehumidification effect, Darwin could achieve the highest annual system electric COP of 25.5 for the SDEC system, 6.2 for the SDCC system, and 3.6 for the SAC system. This is followed by Brisbane with 8.8 for the SDEC system, 2.98 for the SDCC system, and 3.4 for the SAC system. Perth could also achieve a relatively high system electric COP of about 4.3 for the SDEC system, 2.22 for the SDCC system, and 3.09 for the SAC system. This is then followed by Sydney, Adelaide, Melbourne, Canberra, and Hobart. For Hobart, the annual system electric COP is only about 1.12 for the SDEC system, 0.97 for the SDCC system, and 0.92 for the SAC system.

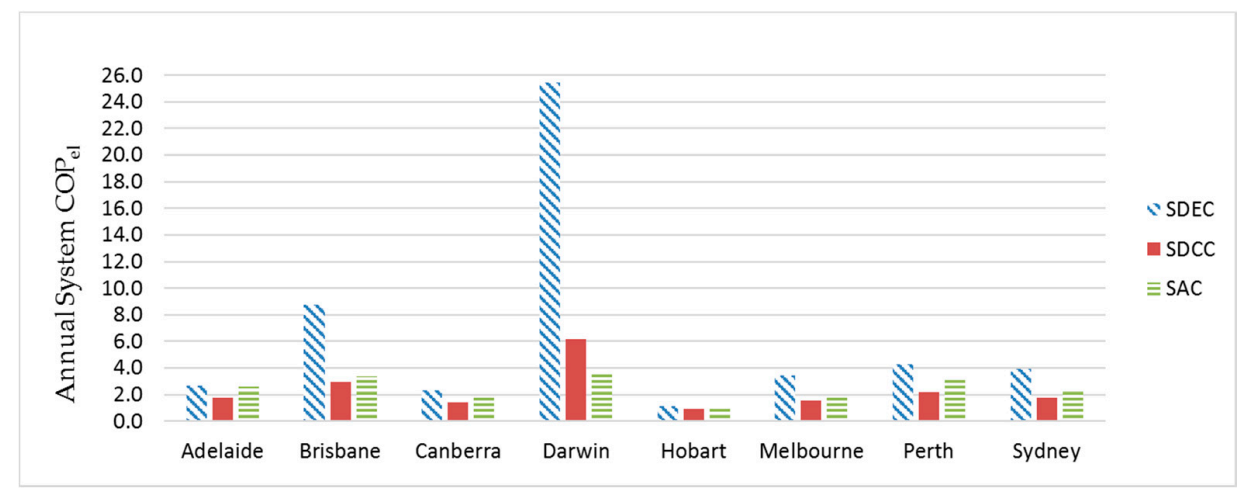

Figure 15. Annual system COP of different solar cooling systems.

It should be noted that the annual system electric $C O P$ performance is strongly consistent with the annual SF performance for each city. This is because the more solar energy utilisation, the less onsite electricity consumption and hence, the more efficient of the system.

Figure 16 demonstrates the correlation between the outdoor air humidity ratio and the system electric COP. The result indicates that the SDEC system has the highest system COP, followed by the SAC system and the SDCC system in general. In addition, with the increase of the outdoor air humidity ratio, the annual electric COP of the solar cooling systems improves gradually. The COP rises dramatically when the outdoor air humidity ratio exceeds $8.8 \mathrm{~g} / \mathrm{kg}$, especially for the SDEC system. This implies that the solar desiccant assisted cooling systems are more efficient for hot and humid climates. A quartic polynomial correlation implies that the SDEC and SDCC systems have a better polynomial fit than the SAC system.

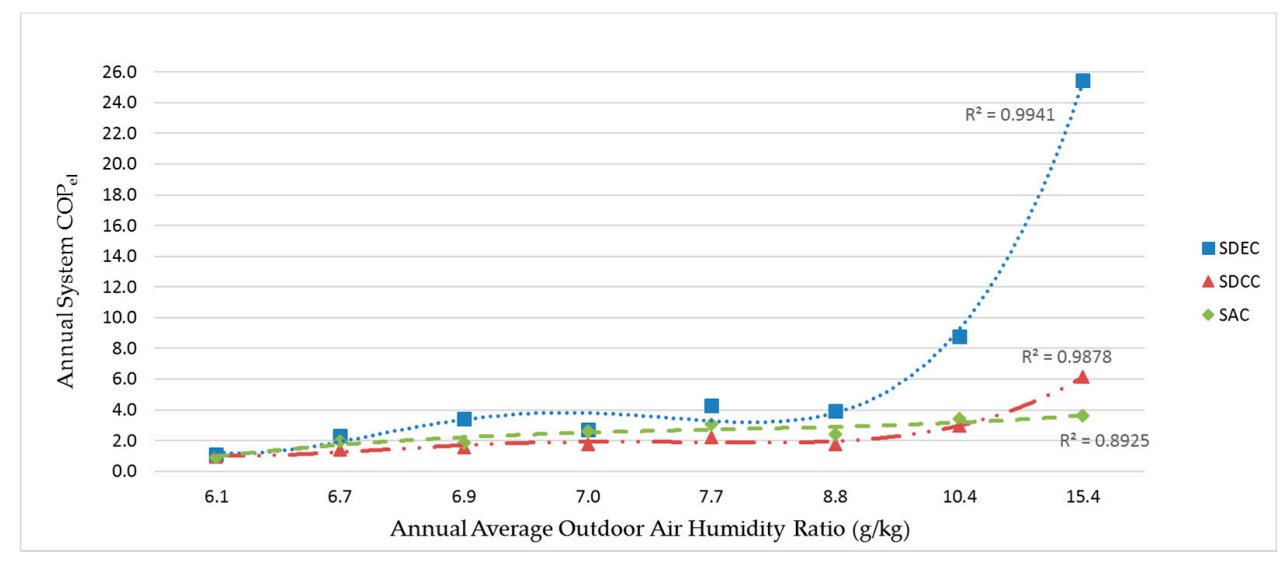

Figure 16. Correlation between outdoor air humidity ratio and annual system COP. 


\subsubsection{Annual HVAC Electricity Energy Consumption}

For all systems, the annual lighting and equipment plug load electricity consumptions are the same in all cities because of the same load intensity. Thus, only the HVAC system electricity consumption in terms of fans, pumps, backup heater, cooling tower, desiccant wheel motor, evaporative coolers, heating, and cooling is analyzed in the section.

Figure 17 demonstrates the annual HVAC electricity energy consumption of the proposed solar-assisted cooling systems compared with the referenced conventional VAV system. It indicates that for Brisbane and Darwin, the SDEC system consumes the least HVAC electricity energy annually. In Brisbane, the SDEC system only consumes 265 GJ electricity annually, compared with the SAC system of $353.3 \mathrm{GJ}$ and the SDCC system of $589.3 \mathrm{GJ}$, which represents $56.9 \%, 42.5 \%$, and $4.1 \%$ annual energy savings respectively to the conventional VAV system. In Darwin, the energy savings potentials for the solar-assisted cooling systems are even more apparent. The SDEC, SDCC and SAC system could achieve 855.88 GJ, 384.34 GJ and 277.67 GJ annual energy savings respectively in comparison with the referenced conventional VAV system, representing $82.1 \%, 36.9 \%$ and $26.6 \%$ corresponding savings.

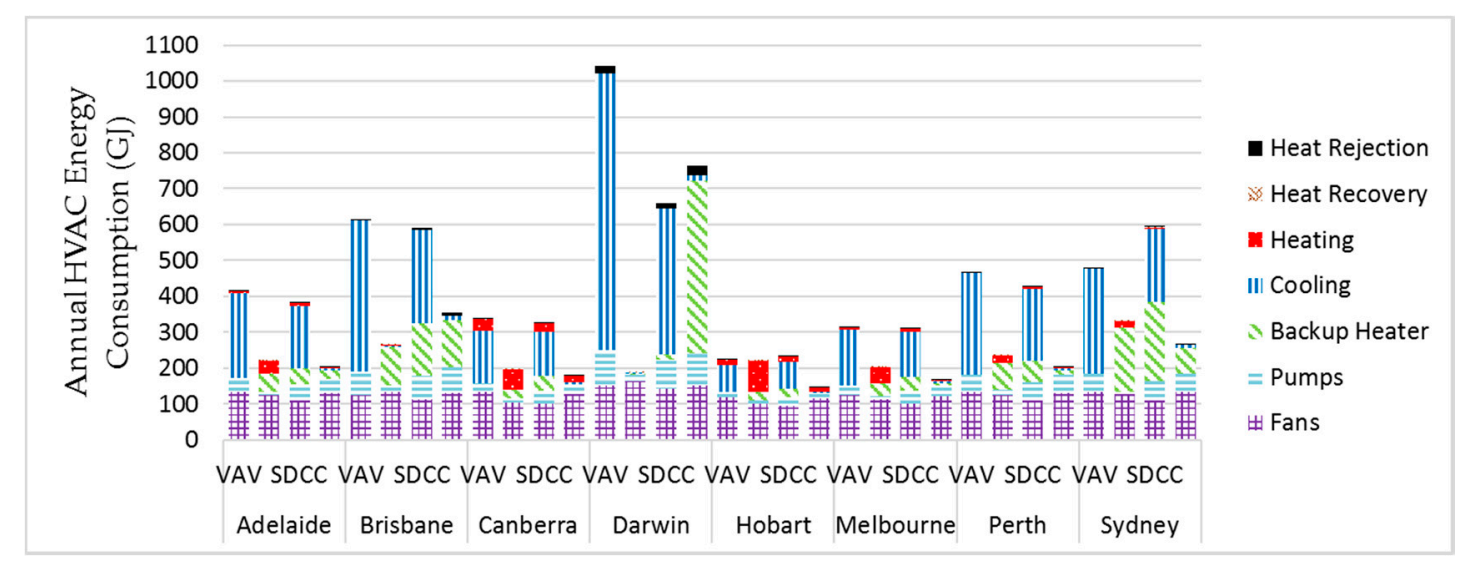

Figure 17. Annual HVAC electricity energy consumption.

However, for the other six cities, the SAC system is the most energy efficient with the lowest annual electricity energy consumption, followed by the SDEC system and SDCC system. The annual HVAC electricity energy consumption for the SAC system is only 204.4 GJ in Adelaide, 179 GJ in Canberra, 146.6 GJ in Hobart, 168.3 GJ in Melbourne, 204.9 GJ in Perth, and 269 GJ in Sydney, which accounts for $50.8 \%, 46.9 \%, 34.4 \%, 46.2 \%, 56.3 \%$ and $43.9 \%$ annual energy savings respectively. The SDEC system energy performance is the second best with $47.4 \%$ savings for Adelaide, $42 \%$ for Canberra, $1.3 \%$ for Hobart, 35.4\% for Melbourne, $49.5 \%$ for Perth and 31.1\% for Sydney respectively. While for the SDCC system, the energy savings potential for these cities is not quite obvious, and the annual energy consumption of the SDCC system for Hobart and Sydney is even more than the conventional VAV system.

\subsection{Environmental Performance Analysis}

The environmental performance analysis of the proposed solar-assisted cooling systems is based on the evaluation of the amount of annual $\mathrm{CO}_{2}$ emissions reduction by saving electricity energy used by air conditioning, which is given by the following formula:

$$
\mathrm{M}_{\mathrm{CO}_{2}}=\mathrm{CO}_{2} \text { factor } \times E_{\text {saved }} \times 0.278,
$$

where $\mathrm{M}_{\mathrm{CO}_{2}}$ is the total annual reduced $\mathrm{CO}_{2}$ emissions in ton; $\mathrm{CO}_{2}$ factor is the emission factor for electricity consumption in $\mathrm{kg} \mathrm{CO}_{2}-\mathrm{e} / \mathrm{kWh}$; and $E_{\text {Saved }}$ is the annual electricity energy savings in GJ. 
The emission factor for each city is shown in Table 8 [63] and the annual HVAC energy savings of the solar cooling systems for each city is demonstrated in Table 9.

Table 8. Emission factors for the consumption of electricity in Australian capital cities ( $\left.\mathrm{kg} \mathrm{CO}_{2}-\mathrm{e} / \mathrm{kWh}\right)$ [63].

\begin{tabular}{cccccccc}
\hline Adelaide & Brisbane & Canberra & Darwin & Hobart & Melbourne & Perth & Sydney \\
\hline 0.81 & 1.00 & 1.06 & 0.75 & 0.33 & 1.35 & 0.93 & 1.06 \\
\hline
\end{tabular}

Table 9. Annual HVAC electricity savings for the solar-assisted cooling systems.

\begin{tabular}{ccccccccl}
\hline (GJ) & ADL & BNE & CBR & DRW & HBA & MEL & PER & SYD \\
\hline SDEC & 196.88 & 349.77 & 141.52 & 855.88 & 2.97 & 110.88 & 232.07 & 149.15 \\
SDCC & 34.14 & 25.51 & 11.77 & 384.34 & -8.65 & 1.96 & 39.89 & -114.13 \\
SAC & 211.22 & 261.5 & 158.03 & 277.64 & 76.86 & 144.5 & 263.71 & 210.92 \\
\hline
\end{tabular}

Then, the annual $\mathrm{CO}_{2}$ emissions reduction for each proposed solar cooling system can be summarized as in Table 10.

Table 10. Annual $\mathrm{CO}_{2}$ emissions reduction.

\begin{tabular}{ccccccccc}
\hline (Tonnes) & ADL & BNE & CBR & DRW & HBA & MEL & PER & SYD \\
\hline SDEC & 44.33 & 97.24 & 41.70 & 178.45 & 0.27 & 41.61 & 60.00 & 43.95 \\
SDCC & 7.69 & 7.09 & 3.47 & 80.13 & -0.79 & 0.74 & 10.31 & -33.63 \\
SAC & 47.56 & 72.70 & 46.57 & 57.89 & 7.05 & 54.23 & 68.18 & 62.15 \\
\hline
\end{tabular}

Table 10 indicates that the annual $\mathrm{CO}_{2}$ emissions reduction is in accordance with the annual HVAC electricity energy savings. Therefore, for Brisbane and Darwin, the SDEC system could avoid the most annual $\mathrm{CO}_{2}$ emissions, which is about 97.24 tonnes and 178.45 tonnes, respectively. While for other cities, the SAC system could achieve the largest annual $\mathrm{CO}_{2}$ emissions reduction of 47.56 tonnes for Adelaide, 46.57 tonnes for Canberra, 7.05 tonnes for Hobart, 54.23 tonnes for Melbourne, 68.18 tonnes for Perth, and 62.15 tonnes for Sydney.

\subsection{Economic Performance Analysis}

Renewable energy integrated air conditioning systems are characterised by high initial cost (IC) and low operating cost (OC) [8]. Initial cost is usually comprised of the investment on the purchase of the equipment and installation cost. Operating cost is the cost required to run the system, which generally includes the fuel cost, materials and labor cost for maintenance. There are a number of different methods that can be adopted to investigate the economic performance of the renewable energy integrated HVAC systems. The payback period $(P B P)$ method and net present value $(N P V)$ method are investigated in this study.

\subsubsection{Payback Period}

Payback period is the simplest method to assess the economic feasibility of solar-assisted cooling systems. It is usually described as the number of years that it takes to recoup the funds expended in an investment. The sooner the system recovers the value of its initial investment, the more desirable it is. The PBP is given by Equation (21) [37]:

$$
P B P=\frac{\triangle I C}{\triangle O C}
$$

where $P B P$ is the payback period in years; $\triangle I C$ is the initial cost differences between the proposed solar-assisted cooling systems and the referenced VAV system; $\triangle O C$ is the operating cost differences 
between the referenced conventional VAV system and the proposed solar system alternatives. The annual system operating cost $O C$ is defined by the following equation [27]:

$$
O C=E_{H V A C} \times C_{e}+C_{m}
$$

where $E_{H V A C}$ is the system total annual energy consumption in $\mathrm{kWh} ; C_{e}$ is the electricity price in $\$ / \mathrm{kWh}$; and $C_{m}$ is the system labour operation and maintenance (O\&M) cost, which is usually expressed by the percent of the system total initial investment cost [64]. The electricity price $C_{e}$ for each city and the system components costs are listed in Tables 11 and 12 below. A currency conversion of 1.1 [65] is used to convert $€$ to $\$$. The central plant equipment capacities are summarised in Appendix A from the simulation results.

Table 11. Electricity fuel cost (c/kWh) [57].

\begin{tabular}{cccccccc}
\hline Adelaide & Brisbane & Canberra & Darwin & Hobart & Melbourne & Perth & Sydney \\
\hline 13.38 & 10.48 & 5.95 & 16.3 & 7.5 & 19.8 & 14.13 & 13.05 \\
\hline
\end{tabular}

Table 12. Assumptions of system equipment costs and O\&M costs.

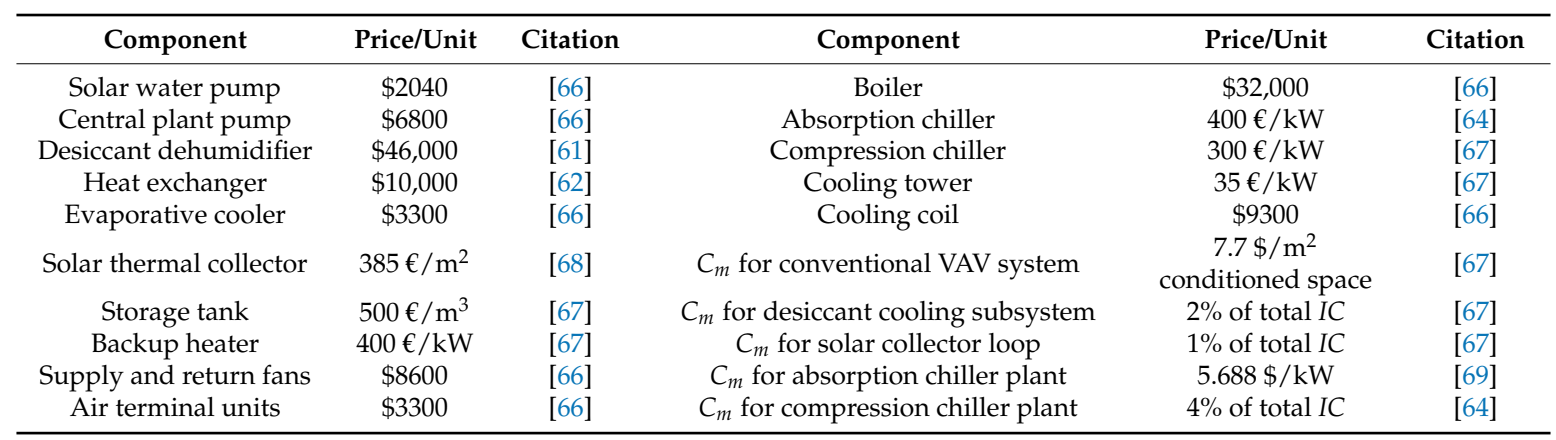

According to the above assumptions, the $P B P$ of the proposed solar-assisted cooling systems for each Australian capital city is illustrated in Table 13. This table illustrates that the SDEC system has the shortest $P B P$ and the SDCC system has the longest $P B P$ for all eight capital cities generally except Darwin. For Darwin, the SDEC system has the lowest PBP of only 3.9 years, followed by the SDCC system of 10.5 years and the SAC system of 12.7 years. For Brisbane, Perth, Adelaide, Sydney and Melbourne, the $P B P$ for the SDEC system ranges from 9.6 years to 12.5 years, while for Hobart, it is as long as 19.9 years. In addition, the SAC system has modest $P B P$ ranging from 12.7 years in Darwin to 16.7 years in Brisbane, except that the $P B P$ is over 20 years in Canberra and Hobart, while for the SDCC system, apart from Darwin with a relatively low $P B P$ of 10.5 years, all other cities have a long $P B P$ of more than 25 years.

Table 13. Payback period of different solar cooling systems.

\begin{tabular}{cccc}
\hline $\boldsymbol{P B P}($ Year) & SDEC & SDCC & SAC \\
\hline Adelaide & 11.4 & 27.3 & 15.8 \\
Brisbane & 9.6 & 29.1 & 16.7 \\
Canberra & 16.2 & 29.8 & 21.8 \\
Darwin & 3.9 & 10.5 & 12.7 \\
Hobart & 19.9 & 30.5 & 23.3 \\
Melbourne & 12.5 & 30.1 & 15.7 \\
Perth & 10.4 & 26.4 & 14.1 \\
Sydney & 12.5 & 61.4 & 16.5 \\
\hline
\end{tabular}




\subsubsection{Net Present Value}

The NPV method determines whether a project will result in a net profile or a loss throughout the life cycle period by calculating the present value of the total benefits and costs which is achieved by discounting the future value of each cash flow [70]. A positive NPV is acceptable and indicates that the benefits exceed the costs. To evaluate if the solar cooling system alternatives would result in a net benefit during the lifespan in comparison with the referenced conventional HVAC system, the NPV is defined using the following formulas by introducing a present worth factor (PWF) [70]:

$$
\begin{gathered}
P W F(N, i, d)=\sum_{j=1}^{N} \frac{(1+i)^{j-1}}{(1+d)^{j}}=\left\{\begin{array}{c}
\frac{1}{d-i}\left[1-\left(\frac{1+i}{1+d}\right)^{N}\right], \text { if } i \neq d, \\
\frac{N}{i+1}, i f i=d \\
N P V=\Delta O C \times P W F-\Delta I C,
\end{array}\right.
\end{gathered}
$$

where PWF implies the present worth factor; $i$ is the inflation rate; $d$ is the discount rate; and $N$ is the lifetime of the system. The economic parameters used to calculate the PWF and NPV are given in Table 14 below. The discount rate is taken to be $8 \%$ in Australia under the assumption that risk capitals are not considered [71].

Table 14. Economic parameters used to calculate the PWF.

\begin{tabular}{cccc}
\hline Component & Value & Unit & Citation \\
\hline System lifetime $N$ & 25 & year & {$[8]$} \\
Inflation rate $i$ & 2.5 & $\%$ & {$[8,52]$} \\
Discount rate $d$ & 8 & $\%$ & {$[52,71,72]$} \\
\hline
\end{tabular}

The NPV results of different solar-assisted cooling system alternatives are then summarised in Table 15. It shows that for Darwin, all three solar-assisted cooling systems resulted in a net benefit during their lifespan. The SDEC could achieve the highest NPV of $\$ 466,199$, followed by the SDCC system of $\$ 71,168$ and the SAC system of $\$ 12,259$. For Adelaide, Brisbane, Melbourne, Perth, and Sydney, only the SDEC system resulted in a positive NPV of $\$ 34,995, \$ 77,842, \$ 13,660$, $\$ 57,663$, and $\$ 11,850$, respectively. However, for Canberra and Hobart, no solar cooling systems could achieve a net benefit during their lifetime. This is because for Canberra and Hobart, the energy savings advantages are not as dramatic as in other cities. It can be seen from the results that the SDEC system is the most economically beneficial for Australian office building applications especially in hot and humid areas such as Darwin and Brisbane. While in cold winter and mild summer climates, for example Canberra and Hobart, solar cooling is not economically feasible compared to the conventional VAV system.

Table 15. Net present value of different solar cooling systems.

\begin{tabular}{cccc}
\hline $\boldsymbol{N P V} \mathbf{( \$ )}$ & SDEC & SDCC & SAC \\
\hline Adelaide & 34,995 & $-138,348$ & $-47,334$ \\
\hline Brisbane & 77,842 & $-146,149$ & $-63,270$ \\
\hline Canberra & $-39,178$ & $-150,498$ & $-116,057$ \\
\hline Darwin & 466,199 & 71,168 & 12,259 \\
\hline Hobart & $-73,857$ & $-153,174$ & $-127,759$ \\
\hline Melbourne & 13,660 & $-150,406$ & $-46,834$ \\
\hline Perth & 57,663 & $-134,400$ & $-18,437$ \\
\hline Sydney & 11,850 & $-211,271$ & $-59,069$ \\
\hline
\end{tabular}

A simple ranking of the proposed solar assisted cooling systems for each Australian capital city is summarized in Table 16 according to different performance criteria discussed above. 
Table 16. Simple system ranking for each city.

\begin{tabular}{|c|c|c|c|c|}
\hline \multirow{2}{*}{ System Ranking } & \multicolumn{4}{|c|}{ Performance Criteria } \\
\hline & $S F$ & COP & Energy & Economic \\
\hline Adelaide & SDEC $>$ SAC $>$ SDCC & $\mathrm{SDEC}>\mathrm{SAC}>\mathrm{SDCC}$ & $\mathrm{SAC}>\mathrm{SDEC}>\mathrm{SDCC}>\mathrm{VAV}$ & $\mathrm{SDEC}>\mathrm{VAV}>\mathrm{SAC}>\mathrm{SDCC}$ \\
\hline Brisbane & $\mathrm{SDEC}>\mathrm{SAC}>\mathrm{SDCC}$ & SDEC $>$ SAC $>$ SDCC & $\mathrm{SDEC}>\mathrm{SAC}>\mathrm{SDCC}>\mathrm{VAV}$ & SDEC $>$ VAV $>$ SAC $>$ SDCC \\
\hline Canberra & $\mathrm{SDEC}>\mathrm{SAC}>\mathrm{SDCC}$ & SDEC $>$ SAC $>$ SDCC & $\mathrm{SAC}>\mathrm{SDEC}>\mathrm{SDCC}>\mathrm{VAV}$ & $\mathrm{VAV}>\mathrm{SDEC}>\mathrm{SAC}>\mathrm{SDCC}$ \\
\hline Darwin & $\mathrm{SDEC}>\mathrm{SAC}>\mathrm{SDCC}$ & $\mathrm{SDEC}>\mathrm{SDCC}>\mathrm{SAC}$ & $\mathrm{SDEC}>\mathrm{SDCC}>\mathrm{SAC}>\mathrm{VAV}$ & $\mathrm{SDEC}>\mathrm{SDCC}>\mathrm{SAC}>\mathrm{VAV}$ \\
\hline Hobart & $\mathrm{SDEC}>\mathrm{SDCC}>\mathrm{SAC}$ & SDEC $>$ SDCC $>$ SAC & $\mathrm{SAC}>\mathrm{SDEC}>\mathrm{VAV}>\mathrm{SDCC}$ & $\mathrm{VAV}>\mathrm{SDEC}>\mathrm{SAC}>\mathrm{SDCC}$ \\
\hline Melbourne & $\mathrm{SDEC}>\mathrm{SAC}>\mathrm{SDCC}$ & $\mathrm{SDEC}>\mathrm{SAC}>\mathrm{SDCC}$ & $\mathrm{SAC}>\mathrm{SDEC}>\mathrm{SDCC}>\mathrm{VAV}$ & $\mathrm{SDEC}>\mathrm{VAV}>\mathrm{SAC}>\mathrm{SDCC}$ \\
\hline Perth & $\mathrm{SDEC}>\mathrm{SAC}>\mathrm{SDCC}$ & SDEC $>$ SAC $>$ SDCC & $\mathrm{SAC}>\mathrm{SDEC}>\mathrm{SDCC}>\mathrm{VAV}$ & $\mathrm{SDEC}>\mathrm{VAV}>\mathrm{SAC}>\mathrm{SDCC}$ \\
\hline Sydney & $\mathrm{SDEC}>\mathrm{SAC}>\mathrm{SDCC}$ & $\mathrm{SDEC}>\mathrm{SAC}>\mathrm{SDCC}$ & $\mathrm{SAC}>\mathrm{SDEC}>\mathrm{VAV}>\mathrm{SDCC}$ & $\mathrm{SDEC}>\mathrm{VAV}>\mathrm{SAC}>\mathrm{SDCC}$ \\
\hline
\end{tabular}

\section{Conclusions}

In this study, the feasibility of solar-assisted cooling technology for a typical office building has been examined from technical, environmental, and economic viewpoints under a variety of Australian climate conditions. Three different types of solar cooling systems, namely the SDEC system, SDCC system, and SAC system, have been investigated using EnergyPlus simulation. The simulation results have shown that solar-assisted cooling technology is technically feasible for Australian office buildings. The SDEC system had the best performance among all systems on the whole in terms of the annual $S F$ and system COP. The annual SF of the SDEC system could achieve 0.82 in hot and humid climate such as Darwin and 0.49 in cold winter mild summer zone such as Hobart. In addition, the annual system electric COP could reach 25.5 in Darwin and 1.12 in Hobart. The SAC system SF and COP performances were the second best, ranging from 0.33 to 0.71 for the annual $S F$ and 0.92 to 3.61 for the annual $C O P$ in different climates.

In related to the energy and environmental performances, all three solar cooling systems consumed less annual HVAC electricity energy than the conventional VAV, system except the SDCC system in Hobart and Sydney. Meanwhile, the SDEC system performed the best in Brisbane and Darwin because of high dehumidification effect. The SDEC system could save about $56.9 \%$ and $82.1 \%$ annual electricity energy in Brisbane and Darwin respectively compared to the conventional VAV system, together with 97.24 tonnes and 178.45 tonnes annual $\mathrm{CO}_{2}$ emissions reduction, while for the other six cities, the SAC system consumed the least electricity energy annually with the most amount of annual $\mathrm{CO}_{2}$ emissions reduction.

The economic analysis has indicated that all the solar-assisted cooling systems are economically applicable in Darwin due to low $P B P$ and positive NPV throughout the lifespan. The PBP in Darwin was only 3.9 years for the SDEC system, 10.5 years for the SDCC system, and 12.7 years for the SAC system, with the total $N P V$ of $\$ 466,199, \$ 71,168$, and $\$ 12,259$ respectively. For Adelaide, Brisbane, Melbourne, Perth and Sydney, only the SDEC system achieved the positive NPV with moderate PBP from 9.6 years to 12.5 years. However, for Canberra and Hobart, the solar-assisted cooling systems were not economically comparable to the conventional VAV system because of high initial cost and low energy savings potential. As the SAC system was still more energy efficient and environmentally friendly than the conventional VAV system in Canberra and Hobart, reducing the initial cost is a key approach to increase the economic benefits for solar-assisted cooling applications in these climates.

Acknowledgments: The authors would like to acknowledge that Queensland University of Technology (QUT) provided the funds for covering the costs to publish in open access. The authors would also like to thank Desiccant Rotors International Pvt. Ltd. and Guangzhou Jiema Heat Exchange Equipment Co., Ltd. to provide data information for the desiccant dehumidifier and air-to-air sensible heat exchanger.

Author Contributions: Yunlong Ma and Lisa Guan conceived the project. Yunlong Ma created the building and system models, and conducted the simulation. All the authors contributed to the data acquisition, results analysis and data interpretation. Yunlong Ma wrote the manuscript. Suvash C. Saha, Wendy Miller, and Lisa Guan provided comments and language editing for the manuscript revisions.

Conflicts of Interest: The authors declare no conflict of interest. 


\section{Nomenclature}

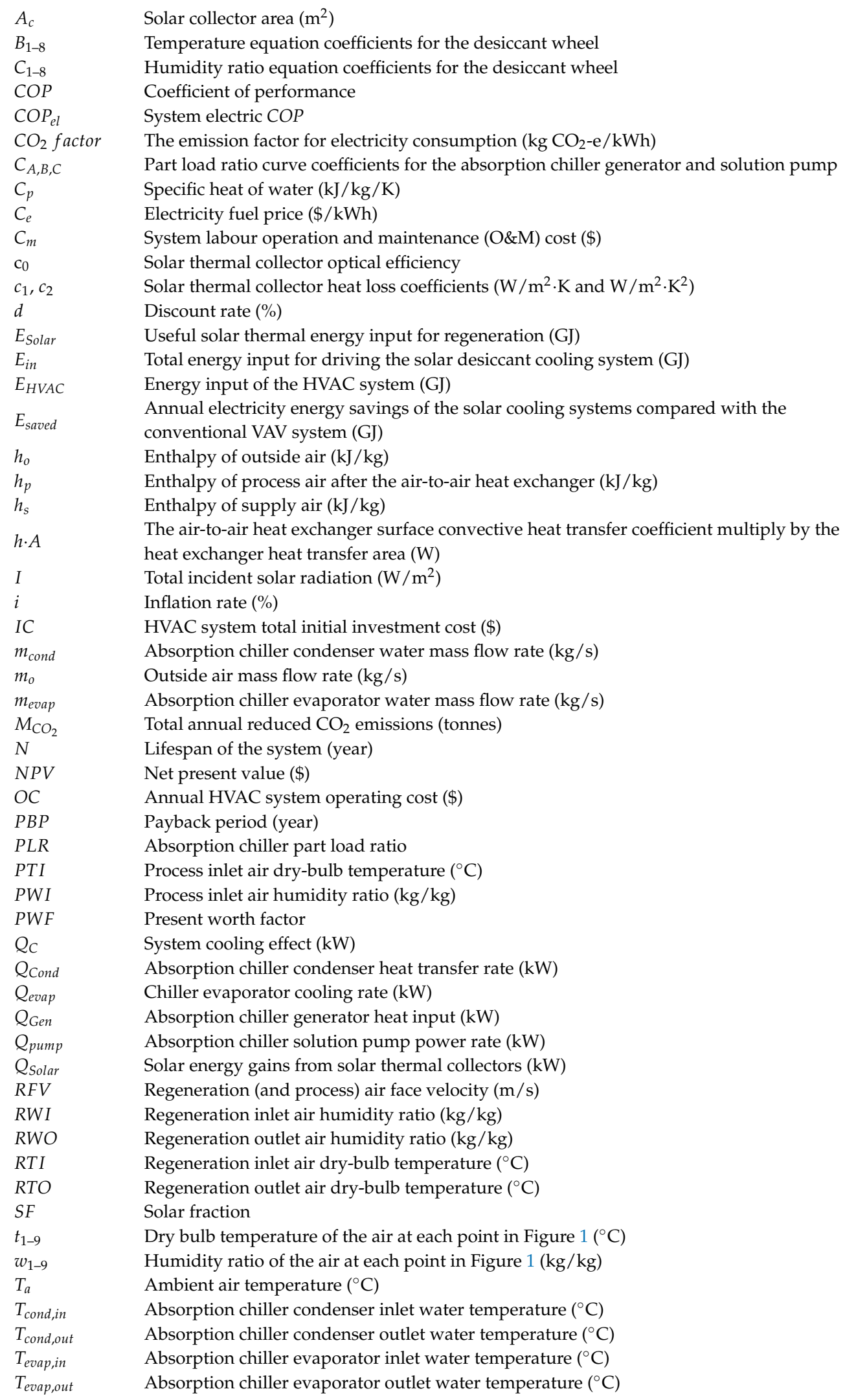




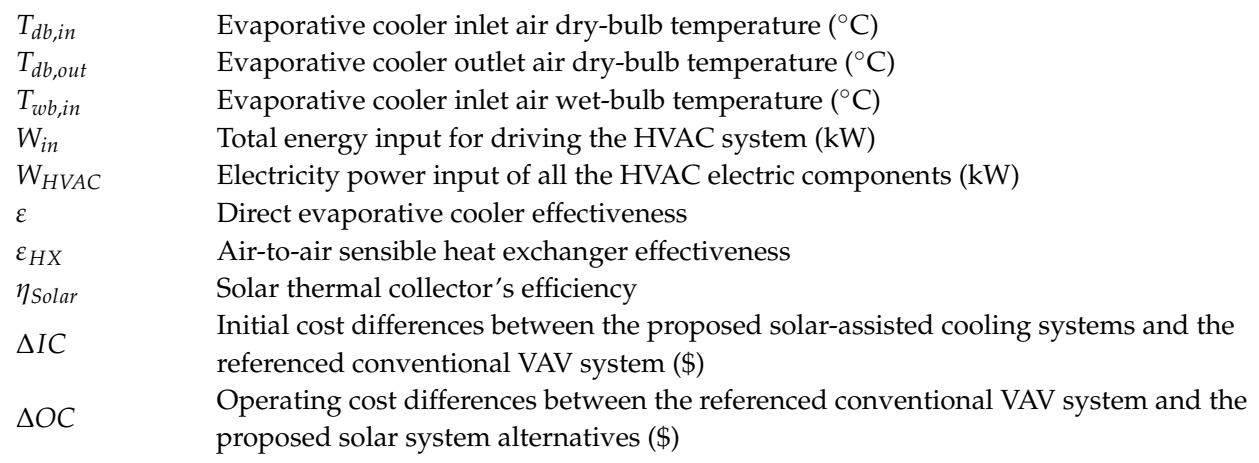

\section{Appendix}

The central plant equipment capacity can be obtained from the simulation outputs as is shown in Table A1 below.

Table A1. Central plant equipment capacity.

\begin{tabular}{cccccccccc}
\hline & kW & ADL & BNE & CBR & DRW & HBA & MEL & PER & SYD \\
\hline \multirow{2}{*}{ VAV } & Compression chiller & 248 & 261 & 226 & 286 & 214 & 234 & 245 & 254 \\
& Cooling tower & 254 & 268 & 232 & 293 & 219 & 240 & 251 & 260 \\
\hline \multirow{2}{*}{ SDCC } & Compression chiller & 110 & 120 & 92 & 143 & 80 & 95 & 108 & 116 \\
& Cooling tower & 113 & 123 & 94 & 146 & 82 & 97 & 111 & 119 \\
\hline \multirow{2}{*}{ SAC } & Absorption chiller & 248 & 280 & 232 & 279 & 221 & 239 & 252 & 268 \\
& Cooling tower & 241 & 270 & 224 & 270 & 211 & 248 & 270 & 265 \\
\hline
\end{tabular}

\section{References}

1. Wrobel, J.; Sanabria Walter, P.; Schmitz, G. Performance of a solar assisted air conditioning system at different locations. Sol. Energy 2013, 92, 69-83. [CrossRef]

2. International Energy Agency. Energy Technology Perspectives 2010: Scenarios \& Strategies to 2050; International Energy Agency: Paris, France, 2010.

3. Boyano, A.; Hernandez, P.; Wolf, O. Energy demands and potential savings in European office buildings: Case studies based on EnergyPlus simulations. Energy Build. 2013, 65, 19-28. [CrossRef]

4. Zhu, S.; Chen, J. A simulation study for a low carbon consumption HVAC project using EnergyPlus. Int. J. Low-Carbon Technol. 2012, 7, 248-254. [CrossRef]

5. Agdas, D.; Srinivasan, R.S.; Frost, K.; Masters, F.J. Energy use assessment of educational buildings: Toward a campus-wide sustainable energy policy. Sustain. Cities Soc. 2015, 17, 15-21. [CrossRef]

6. Baniyounes, A.M.; Ghadi, Y.Y.; Rasul, M.G.; Khan, M.M.K. An overview of solar assisted air conditioning in Queensland's subtropical regions, Australia. Renew. Sustain. Energy Rev. 2013, 26, 781-804. [CrossRef]

7. GeoscienceAustralia; Australian Bureau of Agricultural and Resource Economics and Sciences (ABARE). Australian Energy Resource Assessment; Department of Resources, Energy and Tourism: Canberra, Australia, 2010.

8. Baniyounes, A.M.; Liu, G.; Rasul, M.G.; Khan, M.M.K. Analysis of solar desiccant cooling system for an institutional building in subtropical Queensland, Australia. Renew. Sustain. Energy Rev. 2012, 16, 6423-6431. [CrossRef]

9. Bahadori, A.; Nwaoha, C. A review on solar energy utilisation in Australia. Renew. Sustain. Energy Rev. 2013, 18, 1-5. [CrossRef]

10. Chwieduk, D. Solar Energy in Buildings: Thermal Balance for Efficient Heating and Cooling; Elsevier Inc.: Amsterdam, The Netherlands, 2014.

11. Australian Photovoltaic Institute (APVI). Australian PV Market since April 2001. Available online: pv-map. apvi.org.au (accessed on 4 September 2017).

12. Department of Industry, Innovation and Science. Australian Energy Update 2016; Department of Industry, Innovation and Science: Canberra, Australia, 2016. 
13. Henning, H.-M. Solar assisted air conditioning of buildings-An overview. Appl. Therm. Eng. 2007, 27, 1734-1749. [CrossRef]

14. Eicker, U. Energy Efficient Buildings with Solar and Geothermal Resources; John Wiley \& Sons Ltd.: Hoboken, NJ, USA, 2014.

15. Kotak, Y.; Gago, E.; Mohanty, P.; Muneer, T. Installation of roof-top solar PV modules and their impact on building cooling load. Build. Serv. Eng. Res. Technol. 2014, 35, 613-633. [CrossRef]

16. Arsalis, A.; Alexandrou, A.; Georghiou, G. Thermoeconomic Modeling and Parametric Study of a Photovoltaic-Assisted 1 MWe Combined Cooling, Heating, and Power System. Energies 2016, 9, 663. [CrossRef]

17. Moretti, E.; Bonamente, E.; Buratti, C.; Cotana, F. Development of Innovative Heating and Cooling Systems Using Renewable Energy Sources for Non-Residential Buildings. Energies 2013, 6, 5114-5129. [CrossRef]

18. El May, S.; Sayadi, Z.; Bellagi, A. Feasibility of air-cooled solar air-conditioning in hot arid climate regions. Int. J. Sustain. Energy 2009, 28, 183-193. [CrossRef]

19. Assilzadeh, F.; Kalogirou, S.A.; Ali, Y.; Sopian, K. Simulation and optimization of a LiBr solar absorption cooling system with evacuated tube collectors. Renew. Energy 2005, 30, 1143-1159. [CrossRef]

20. Tsoutsos, T.; Aloumpi, E.; Gkouskos, Z.; Karagiorgas, M. Design of a solar absorption cooling system in a Greek hospital. Energy Build. 2010, 42, 265-272. [CrossRef]

21. Eicker, U.; Pietruschka, D. Design and performance of solar powered absorption cooling systems in office buildings. Energy Build. 2009, 41, 81-91. [CrossRef]

22. Mateus, T.; Oliveira, A.C. Energy and economic analysis of an integrated solar absorption cooling and heating system in different building types and climates. Appl. Energy 2009, 86, 949-957. [CrossRef]

23. Stanciu, C.; Stanciu, D.; Gheorghian, A.-T. Thermal Analysis of a Solar Powered Absorption Cooling System with Fully Mixed Thermal Storage at Startup. Energies 2017, 10, 72. [CrossRef]

24. Hassan, H. Performance Evaluation of a Continuous Operation Adsorption Chiller Powered by Solar Energy Using Silica Gel and Water as the Working Pair. Energies 2014, 7, 6382-6400. [CrossRef]

25. Umair, M.; Akisawa, A.; Ueda, Y. Performance Evaluation of a Solar Adsorption Refrigeration System with a Wing Type Compound Parabolic Concentrator. Energies 2014, 7, 1448-1466. [CrossRef]

26. Li, Y.; Yang, H. Investigation on solar desiccant dehumidification process for energy conservation of central air-conditioning systems. Appl. Therm. Eng. 2008, 28, 1118-1126. [CrossRef]

27. Li, Y.; Lu, L.; Yang, H. Energy and economic performance analysis of an open cycle solar desiccant dehumidification air-conditioning system for application in Hong Kong. Sol. Energy 2010, 84, 2085-2095. [CrossRef]

28. Abdel-Salam, A.H.; Ge, G.; Simonson, C.J. Thermo-economic performance of a solar membrane liquid desiccant air conditioning system. Sol. Energy 2014, 102, 56-73. [CrossRef]

29. Dezfouli, M.M.S.; Mat, S.; Pirasteh, G.; Sahari, K.S.M.; Sopian, K.; Ruslan, M.H. Simulation Analysis of the Four Configurations of Solar Desiccant Cooling System Using Evaporative Cooling in Tropical Weather in Malaysia. Int. J. Photoenergy 2014, 2014, 1-14. [CrossRef]

30. Li, H.; Dai, Y.J.; Li, Y.; La, D.; Wang, R.Z. Case study of a two-stage rotary desiccant cooling/heating system driven by evacuated glass tube solar air collectors. Energy Build. 2012, 47, 107-112. [CrossRef]

31. Mazzei, P.; Minichiello, F.; Palma, D. Desiccant HVAC systems for commercial buildings. Appl. Therm. Eng. 2002, 22, 545-560. [CrossRef]

32. Ma, Y.; Guan, L. Performance Analysis of Solar Desiccant-Evaporative Cooling for a Commercial Building under Different Australian Climates. Procedia Eng. 2015, 121, 528-535. [CrossRef]

33. Angrisani, G.; Roselli, C.; Sasso, M.; Tariello, F.; Vanoli, G. Performance Assessment of a Solar-Assisted Desiccant-Based Air Handling Unit Considering Different Scenarios. Energies 2016, 9, 724. [CrossRef]

34. Rafique, M.; Rehman, S.; Alhems, L.; Lashin, A. Parametric Analysis of a Rotary Type Liquid Desiccant Air Conditioning System. Energies 2016, 9, 305. [CrossRef]

35. Rafique, M.; Rehman, S.; Lashin, A.; Al Arifi, N. Analysis of a Solar Cooling System for Climatic Conditions of Five Different Cities of Saudi Arabia. Energies 2016, 9, 75. [CrossRef]

36. Nie, J.; Li, Z.; Hu, W.; Fang, L.; Zhang, Q. Theoretical modelling and experimental study of air thermal conditioning process of a heat pump assisted solid desiccant cooling system. Energy Build. 2017, 153, 31-40. [CrossRef] 
37. Fong, K.F.; Lee, C.K.; Chow, T.T. Comparative study of solar cooling systems with building-integrated solar collectors for use in sub-tropical regions like Hong Kong. Appl. Energy 2012, 90, 189-195. [CrossRef]

38. Hartmann, N.; Glueck, C.; Schmidt, F.P. Solar cooling for small office buildings: Comparison of solar thermal and photovoltaic options for two different European climates. Renew. Energy 2011, 36, 1329-1338. [CrossRef]

39. Eicker, U.; Pietruschka, D.; Schmitt, A.; Haag, M. Comparison of photovoltaic and solar thermal cooling systems for office buildings in different climates. Sol. Energy 2015, 118, 243-255. [CrossRef]

40. Beccali, M.; Cellura, M.; Finocchiaro, P.; Guarino, F.; Longo, S.; Nocke, B. Life cycle performance assessment of small solar thermal cooling systems and conventional plants assisted with photovoltaics. Sol. Energy 2014, 104, 93-102. [CrossRef]

41. Baniyounes, A.M.; Liu, G.; Rasul, M.G.; Khan, M.M.K. Comparison study of solar cooling technologies for an institutional building in subtropical Queensland, Australia. Renew. Sustain. Energy Rev. 2013, 23, 421-430. [CrossRef]

42. Fong, K.F.; Chow, T.T.; Lee, C.K.; Lin, Z.; Chan, L.S. Comparative study of different solar cooling systems for buildings in subtropical city. Sol. Energy 2010, 84, 227-244. [CrossRef]

43. Fong, K.F.; Chow, T.T.; Lee, C.K.; Lin, Z.; Chan, L.S. Advancement of solar desiccant cooling system for building use in subtropical Hong Kong. Energy Build 2010, 42, 2386-2399. [CrossRef]

44. Fong, K.F.; Lee, C.K.; Chow, T.T.; Fong, A.M.L. Investigation on solar hybrid desiccant cooling system for commercial premises with high latent cooling load in subtropical Hong Kong. Appl. Therm. Eng. 2011, 31, 3393-3401. [CrossRef]

45. Fong, K.F.; Chow, T.T.; Lee, C.K.; Lin, Z.; Chan, L.S. Solar hybrid cooling system for high-tech offices in subtropical climate-Radiant cooling by absorption refrigeration and desiccant dehumidification. Energy Convers. Manag. 2011, 52, 2883-2894. [CrossRef]

46. Gagliano, A.; Patania, F.; Nocera, F.; Galesi, A. Performance assessment of a solar assisted desiccant cooling system. Therm. Sci. 2014, 18, 563-576. [CrossRef]

47. Khan, Y.; Singh, G.; Mathur, J.; Bhandari, M.; Srivastava, P. Performance assessment of radiant cooling system integrated with desiccant assisted DOAS with solar regeneration. Appl. Therm. Eng. 2017, 124, 1075-1082. [CrossRef]

48. Baniyounes, A.M.; Rasul, M.G.; Khan, M.M.K. Assessment of solar assisted air conditioning in Central Queensland's subtropical climate, Australia. Renew. Energy 2013, 50, 334-341. [CrossRef]

49. Alizadeh, S. A Feasibility Study of Using Solar Liquid-Desiccant Air Conditioner in Queensland, Australia. J. Sol. Energy Eng. 2008, 130, 021005. [CrossRef]

50. Goldsworthy, M.; White, S. Optimisation of a desiccant cooling system design with indirect evaporative cooler. Int. J. Refrig. 2011, 34, 148-158. [CrossRef]

51. White, S.D.; Kohlenbach, P.; Bongs, C. Indoor temperature variations resulting from solar desiccant cooling in a building without thermal backup. Int. J. Refrig. 2009, 32, 695-704. [CrossRef]

52. Kohlenbach, P.; Dennis, M. Solar Cooling in Australia: The Future of Air Conditioning? In Proceedings of the 9th IIR Gustav Lorentzen Conference, Sydney, Australia, 12-14 April 2010.

53. Byrnes, L.; Brown, C.; Foster, J.; Wagner, L.D. Australian renewable energy policy: Barriers and challenges. Renew. Energy 2013, 60, 711-721. [CrossRef]

54. American Society of Heating, Refrigerating and Air-Conditioning Engineers, Inc. (ASHRAE). ANSI/ASHRAE/IES Standard 90.1-2016, Energy Standard for Buildings Except Low-Rise Residential Buildings; American Society of Heating, Refrigerating and Air-Conditioning Engineers, Inc.: Atlanta, GA, USA, 2016.

55. Ma, Y.; Saha, S.C.; Miller, W.; Guan, L. Parametric Analysis of Design Parameter Effects on the Performance of a Solar Desiccant Evaporative Cooling System in Brisbane, Australia. Energies 2017, 10, 849. [CrossRef]

56. Australian Building Codes Board. ABCB Energy Modelling of Office Buildings For Climate Zoning (Class 5 Climate Zoning Consultancy) Stages 1, 2 \& 3; Australian Building Codes Board: Glen Iris, Australia, 2002.

57. Ma, Y. Investigation of Advanced Solar-assisted Cooling for Australian Commercial Buildings. Master's Thesis, Queensland University of Technology, Brisbane, Australia, 2016.

58. SOLAVIS. Flat Plate Collectors v. Evacuated Tubes-A Brief Overview. Available online: www.solarvis.com.au (accessed on 4 May 2017).

59. Selke, T.; Frein, A. Collection of Good Practices for DEC Design and Installation; IEA Solar Heating and Cooling Program: 2015, Task 48-Activity B2 Final Report, November 2015; Daniel Mugnier: Perpignan, France, 2015; Available online: http:/ /task48.iea-shc.org/publications (accessed on 4 May 2017). 
60. U.S. Department of Energy. EnergyPlus Engineering Reference. Available online: https:/ / energyplus.net/ documentation (accessed on 5 January 2016).

61. Desiccant Rotors International Pvt. Ltd. Technical Specification of ECO-DRY Desiccant Cassette. Available online: http:/ / www.drirotors.com/ (accessed on 17 September 2015).

62. Guangzhou Jiema Heat Exchange Equipment Co., Ltd. Air to Air Heat Exchanger. Available online: www.jiema-heatexchangers.com (accessed on 5 January 2016).

63. Lecamwasam, L.; Wilson, J.; Chokolich, D. Guide to Best Practice Maintenance \& Operation of HVAC Systems for Energy Efficiency; Department of Climate Change and Energy Efficiency: Canberra, Australia, 2012.

64. Tsoutsos, T.; Anagnostou, J.; Pritchard, C.; Karagiorgas, M.; Agoris, D. Solar cooling technologies in Greece. An economic viability analysis. Appl. Therm. Eng. 2003, 23, 1427-1439. [CrossRef]

65. OANDA Corporation. Available online: https://www.oanda.com/currency/converter/ (accessed on 23 August 2016).

66. Rawlinsons. Australian Construction Handbook; Rawlinsons: Perth, Australia, 2011.

67. Henning, H.-M. Solar-Assisted Air-Conditioning in Buildings, 2nd ed.; Springer Wien NewYork: Stefan, Austria, 2007.

68. Bakker, M.; Zondag, H.A.; Elswijk, M.J.; Strootman, K.J.; Jong, M.J.M. Performance and costs of a roof-sized PV/thermal array combined with a ground coupled heat pump. Sol. Energy 2005, 78, 331-339. [CrossRef]

69. Ghadamian, H.; Hamidi, A.A.; Farzaneh, H.; Ozgoli, H.A. Thermo-economic analysis of absorption air cooling system for pressurized solid oxide fuel cell/gas turbine cycle. J. Renew. Sustain. Energy 2012, 4, 043115. [CrossRef]

70. Duffie, J.A.; Beckman, W.A. Solar Engineering of Thermal Processes, 4th ed.; John Wiley \& Sons, Inc.: Hoboken, NJ, USA, 2013.

71. Wang, X.; Bierwirth, A.; Christ, A.; Whittaker, P.; Regenauer-Lieb, K.; Chua, H.T. Application of geothermal absorption air-conditioning system: A case study. Appl. Therm. Eng. 2013, 50, 71-80. [CrossRef]

72. Donnelly, E. Economic Analysis of Energy Provisions for Base Building Fabric Elements of Air-Conditioned Office Spaces; Australian Building Codes Board: Canberra, Australia, 2004.

(C) 2017 by the authors. Licensee MDPI, Basel, Switzerland. This article is an open access article distributed under the terms and conditions of the Creative Commons Attribution (CC BY) license (http:/ / creativecommons.org/licenses/by/4.0/). 